\title{
Fluidumok, áramlási rendszerek és ásványtani lenyomataik összefüggései a Budai-termálkarszton
}

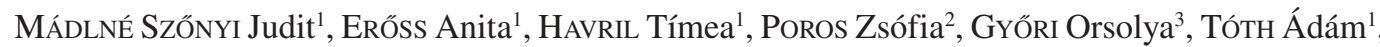 \\ Csoma Anita ${ }^{4}$, Paola RonchI ${ }^{5}$, MindsZEnTy Andrea ${ }^{1}$ \\ 1Eötvös Loránd Tudományegyetem, Általános és Alkalmazott Földtani Tanszék, 1117 Budapest, Pázmány P. sétány 1/C \\ ${ }^{2}$ ConocoPhillips, Houston, USA, TX 77252-2197600 North Dairy Ashford (77079-1175) P.O. Box 2197 \\ ${ }^{3}$ MTA-ELTE Geológiai, Geofizikai és Ûrtudományi Kutatócsoport, 1117 Budapest, Pázmány P. sétány 1/ C \\ ${ }^{4}$ MOL Nyrt. 1117 Budapest, Október huszonharmadika u. 18 \\ ${ }^{5}$ Eni Spa, Róma, Olaszország, Piazzale Enrico Mattei, 100144 \\ 'e-mail: szjudit@ludens.elte.hu, ORCID: 0000-0002-5628-4386
}

\section{Fluids, flow systems and their mineralogical imprints in the Buda Thermal Karst}

Abstract

The fluid evolution of the Buda Thermal Karst (BTK) has been ongoing since the Late Miocene. At that time the system was fully confined and only the thermal buoyancy influenced the flow of fluids in the system. Parallel with the uplift of the Buda Hills, the infiltration of fresh water into the system began; thus the subsequent evolution of the topography-driven groundwater flow brought about the superposition of the two fluid flow systems. This occurred with different prevailing driving forces: namely, the topography in the upper part and buoyancy in the lower. The uplift of the Gödöllő Hills also had an influence on the processes of the BTK and resulted in the evolution of fluid flow heading from the eastern, confined part of the system towards the River Danube. Consequently, the dominantly basinal fluids of the confining strata infiltrated into the underlying carbonate aquifers filled with meteoric water via vertical leakage. These changes were followed in the mineral paragenesis of the BTK. The western region of the BTK is part of the NE Transdanubian Range and nowadays the carbonate aquifers are semi- or unconfined. The springs of this area represent the terminal points of local, intermediate and regional flow systems and they display the rock-water interaction along the flow path. The evaluation of the flow pattern could reveal the West-East direction of flow under the River Danube and the upwelling of fluids towards the discharge areas along the River Danube in the upper, shallow part of the system. The $\mathrm{NaCl}$-type basinal fluids originated from the eastern-confining layers and they contribute to the regional flow component. West-Southwest of the River Danube, $\mathrm{Mg}^{2+}$ - and $\mathrm{SO}_{4}{ }^{2}$ - rich water can be found. The results represent the hydraulically continuous flow sytem of the BTK, the asymmetric flow pattern at the boundary of unconfined and confined carbonate aquifers and, moreover, the significance of confining layers in the accumulation and dissipation of heat. The pressure conditions present in the system are nearly hydrostatic. The NE Marginal Fault also has a role in the differentiation of the discharge areas at the foothills of the Rózsadomb and the Gellért Hill. In the area behind the Gellért Hill an intermediate flow system appears; therefore, at the foothills of the Gellert Hill only thermal water is discharged. At the Rózsadomb the lukewarm and hydrothermal fluid discharge areas are close to each other. Thus the evidence strongly suggests that the respective hydrothermal components of the Central and Southern systems differ. The $\mathrm{NaCl}-$ type water of the eastern half of the basin contributes to the discharge of the regional flow path of the Central system. This system transfers $\mathrm{H}_{2} \mathrm{~S}$ and $\mathrm{CH}_{4}$ to the springs. In the case of the Southern System, the excess of sulphate in the water is more prevalent, and this may be in connection with the evaporite layers in the SW. On the basis of sulphur isotope analysis, the meteoric fluid component of the Rózsadomb receives its sulphur during infiltration through a pyrite-rich covering strata. The brief details mentioned here suggest that a better understanding of the fluid evolution of the BTK will contribute to the interpretation of hypogenic karstification and cave evolution in the area.

Keywords: fluid evolution, topography driven groudwater flow systems, buoyancy force, sulphur isotope, Buda Thermal Karst, Gödölló Hills

Összefoglalás

A Budai-termálkarszt (BTK) fluidum-fejlődéstörténetét az ásványparagenezisek tükrében a késő-miocén fedett karbonátos állapottól vizsgáltuk. Ekkor a termikus felhajtóerő vezérelte a felszín alatti vízáramlást. Később, a Budaihegység kiemelkedésével és a csapadékvíz beszivárgásával megkezdődött a vízszintkülönbségek által vezérelt vízáramlási rendszerek kialakulása. További változást okozott a Gödöllői-dombság kiemelkedése, mely a Budai-hegység kiemelt területei mellett a keleti medencerész felől is domborzati hajtóerőt biztosított. A meginduló beszivárgás lehetővé tette a fedő sziliciklasztos képződmények nátrium-kloridos vizeinek karbonátos víztartóba történő lejutását. Jelenleg a Budaihegység és tágabb környezete a BTK áramlási rendszerének nyugati, félig fedett részét, míg a Gödöllői-dombságtól a 
Dunáig tartó terület a rendszer keleti, fedett részét képezi. A BTK összefüggő áramlási rendszerében hidrosztatikushoz közeli nyomásviszonyok uralkodnak. A rendszer regionális és köztes megcsapolódási területei a Duna mentén húzódnak. A helyi, köztes és regionális áramlási rendszerek különbségeit a nyugati, félig fedett terület forrásai jelzik. A jelenkori vízáramlás domináns hajtóereje a vízszintkülönbségekből fakad, asszimmetrikus jellege a hidrosztratigráfiai helyzet, valamint a keleti és nyugati medencerészek közötti beszivárgáskülönbség következménye. A Duna alatt Ny-K irányú regionális átáramlás zajlik. A regionális feláramlás hidrotermális komponense NaCl-os medenceeredetú vízzel egészül ki. A meteorikus eredetû, langyos köztes, ill. a hideg helyi vízáramlásokban $\mathrm{Mg}^{2+}$ és $\mathrm{SO}_{4}^{2-}$ gazdag vizek jellemzőek, a medenceeredetú fluidumok jelenléte itt nem bizonyított. Az eredmények rámutatnak a rendszer hőmérsékleti eloszlását meghatározó folyamatokra, valamint a fedőüledékek hőfelhalmozódásban betöltött szerepére. A rózsadombi és a Gellérthegy előterében található források fizikai-kémiai tulajdonságok szerinti elkülönülését szerkezeti és a két áramlási rendszer különbségei okozhatják. A Gellért-hegynél csak termálvíz lép felszínre, míg a Rózsadombnál langyos és termálvíz megcsapolódás egyaránt zajlik. A különbség a hidrotermális vizek összetételében, eltérő forrásterületre és vízkémiai folyamatokra utal. A déli rendszer szulfáttöbblete az evaporitösszletekkel, a központi rendszer szulfátja medenceeredetú kén-hidrogénnel hozható összefüggésbe. A rózsadombi langyos meteorikus vizek szulfátforrása a fedő képződménybek piritje lehet. A fluidum-fejlődéstörténeti tanulmány eredményei hozzájárulnak a barlangképződési folyamatok értelmezéséhez.

Tárgyszavak: fluidum-fejlődéstörténet, gravitációs áramlási rendszerek, termikus felhajtóerô, kénizotóp, Budai-termálkarszt, Gödöllőidombság

\section{Bevezetés, elốzmények}

A Budai-termálkarszt (BTK) évszázadok óta a geológusok, barlangászok, ásványtani szakemberek és hidrogeológusok kutatásainak középpontjában áll termálvízkincse, az utóbbi évszázadban felfedezett barlangjai, azok ásvány paragenezisei, valamint a fôváros urbángeológiai vonatkozásai miatt (1. ábra). A számos, e témában született publikáció közül a teljesség igénye nélkül kiemelhetô MinDSZENTY (2013) összefoglaló munkája, mely a terület földtani, geomorfológiai, vízföldtani kutatástörténetét és adatottságait, a források és az édesvízi mészkövek viszonyát, valamint barlangtani kérdéseket tárgyal, továbbá rávilágít az adottságok hasznosítási és természetvédelmi jelentőségére Budapest életében. Gyalog et al. (2016) kiadványa a földtani viszonyokat foglalja össze. VIRÁG (2016) a budai barlangok keletkezéséról, a termálkarsztos, illetve a hidrotermális eseményekkel foglalkozó szakirodalmakról közölt kutatástörténeti tanulmányt. LEÉL-ỐssY (2017) a Budai-termálkarszt barlangjairól publikált. A fent idézett munkákban a témában szinte valamennyi korábban született szakirodalom fellelhetô, melyek egyedi hivatkozásától sokaságuk okán itt eltekintünk.

Felmerül a kérdés, hogy egy ilyen sokoldalúan és részletesen feltárt területen tudományos értelemben lehet-e „újat mondani”, és ha igen, hogyan és milyen módon? A válaszadásnál figyelembe kell vennünk, hogy a kutatási területen, kiemelten Budapesten, az emberi beavatkozások megnehezítik a kutatók szándékát, hogy a természeti folyamatokat értelmezzék. A továbblépés kulcsa TóTH J. (1999) megközelítésében rejlik, aki felvázolta a felszín alatti víz földtani hatótényezố szerepét, azaz a földtani időskálán múködố felszín alatti vízáramlási rendszerek kózetvázra gyakorolt hatásának mechanizmusait. Ennek megfelelóen összefüggéseket kereshetünk az áramlási rendszerekben mozgó víz, valamint a víz-kôzet kölcsönhatás földtani rétegsorokban hagyott nyomai között. Ennek jegyében indultak el az ELTE Alkalmazott és Környezetföldtani Tanszék rózsadombi termálkarsztos kutatásai (MINDSZENTY \& MÁDL-SZŐNYI 1999, MindSZENTY et al. 2001, MindsZENTY et al. 2000). A Budai- termálkarsztra vonatkozó tanszéki kutatások később (20072011) két, egymással párhuzamosan futó, iparilag támogatott (Shell, Eni) projekt formájában folytatódtak (ERóss et al. 2011a, PoROs 2010). A hidrogeológiai felfedező kutatások (2011-2017) következő szakasza egy interdiszciplináris OTKA pályázat volt. E kutatások egészültek ki a Paleogénmedencére - a Mol NyRt. megbízásából (2011-2013) végzett, a fluidumokat érintő alkalmazott kutatással (MÁDLNÉ SZŐNYI et al. 2013).

Hagyományosan a BTK-n belül, Budapesten három természetes forrásfeltörési helyet különítünk el. Az északi területeken (Csillag-hegy) csak langyos vizek, a központi területen (József-hegy vagy Rózsadomb) langyos és termálvizek, míg a déli területen (Gellért-hegy) csak termálvizek lépnek a felszínre (ALFÖLDI et al. 1968; ERŐss et al. 2008, 2012a; PAPP 1942). E tanulmányban csak a központi és déli területek kútjaival és forrásaival foglalkozunk. Az ún. központi rendszer alatt a Rózsadomb előterében található forrásfakadások mellett a Lukács kutakat, a margitszigeti és az észak-pesti kutakat értjük. Az ún. déli rendszerhez soroljuk a Gellért-hegy elôterében található forrásfakadások mellett a Gellért-hegy elôterében található (Gellért, Rudas és Rác fürdô) kútjait, továbbá a dél-budai és pesti kutakat (lásd később 1., 2., 3. ábra). A két rendszer határai korábbi irodalmi munkák alapján nem ismertek.

A fentiekben vázolt kutatások alapján tanulmányunk a következő kérdésekre kíván választ adni. Hogyan alakultak a miocéntől kezdve napjainkig a vízáramlást okozó hajtóerők, valamint - az ásványfázisok tükrében — a fluidum komponensek a BTK vízáramlási rendszerében? Mi jellemzi a BTK jelenlegi regionális léptékú vízáramlását a rendszer határai, nyomásviszonyai, vízáramlási rendszerei és fluidum komponensei tekintetében? Miben hasonlít és miben tér el egymástól a BTK központi és déli rendszere, ill. mi magyarázhatja az eltéréseket? E kérdések megválaszolásával a BTK új, regionális vízföldtani szintézisének kidolgozásához kívánunk hozzájárulni.

A cikkben a fluidum kifejezést SCHUBERT et al. (2007) értelmezésében használjuk ott, ahol a folyadék és gázfázisok együttesére gondolunk. A meteorikus víz fogalmát a 
csapadékból származtatható vizekre használjuk. A medencefluidum elnevezést a származását tekintve tengeri eredetû, kémiailag módosult összetételú, de jellegét tekintve nátrium-kloridos fluidumokra használjuk. Mindkét esetben, DEMING (2002) értelmezését követjük.
Tanulmányunkban a többnyire különálló cikkek formájában, angol nyelven közölt eredményeinket szintetizáljuk a feltett kérdések tükrében, valamint korábban nem publikált $\delta^{34} \mathrm{~S}$ vizsgálati eredményekkel egészítjük ki, melyek csak doktori dolgozatban, konferencia közleményekben vagy

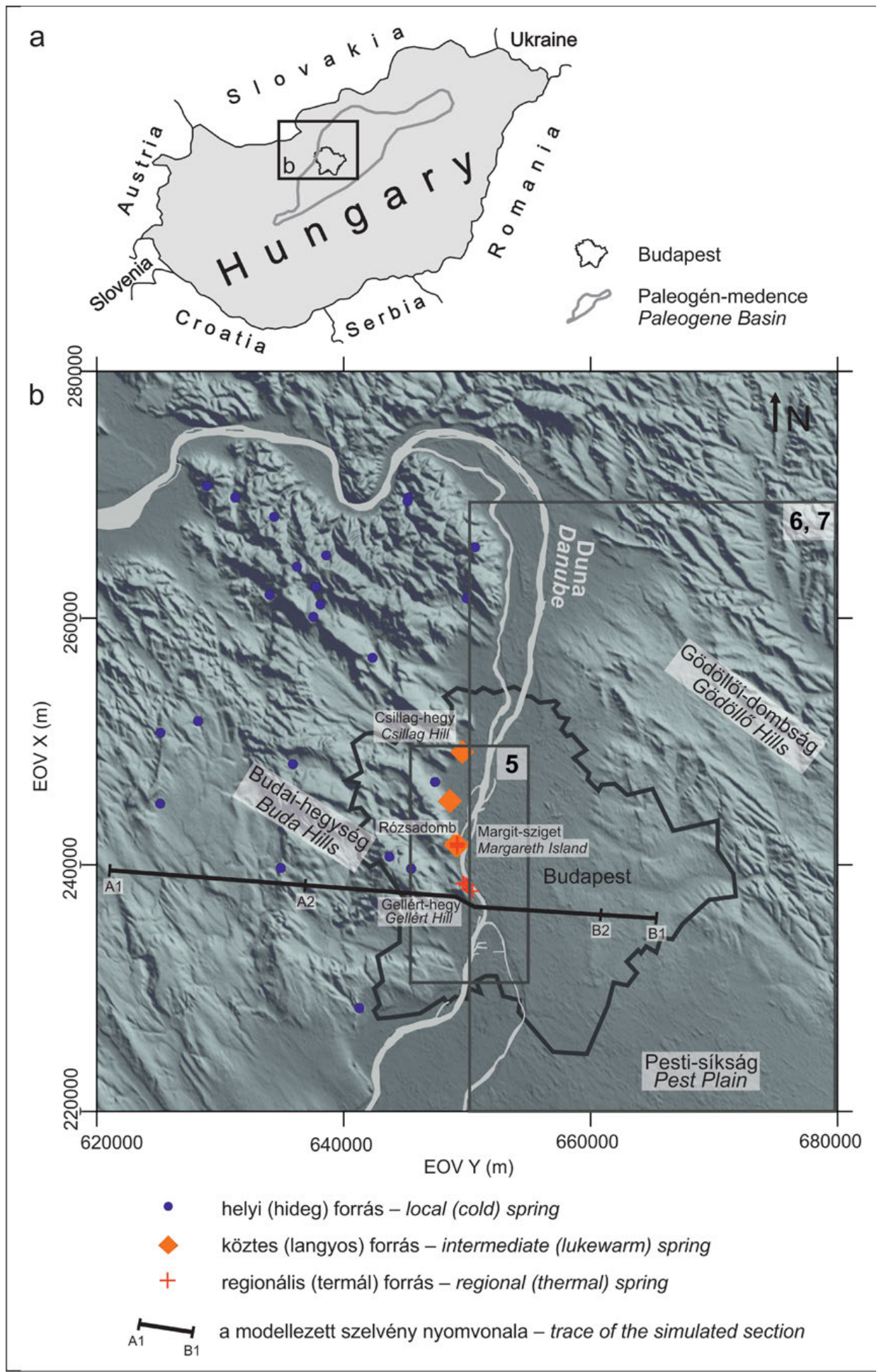

1. ábra. A Budai-termálkarszt vizsgálati területe, a Rózsadomb és a Gellért-hegy megcsapolódási terület, a források elhelyezkedése, valamint a modellezett szelvény és térképkivágatok

Figure 1. The Buda Thermal Karst area, discharge area of the Rózsadomb and Gellert Hill, springs, the trace of the simulated section and insets of further figures 
kutatási jelentésekben szerepeltek. Az eredeti adatok közlésétől, azok minőségi, megbízhatósági értékelésétől itt eltekintünk, ezek a hivatkozott publikációinkban megtalálhatók. A tanulmány újdonsága mindezen ismeretek szintézisében rejlik. A dolgozat jellege miatt az alkalmazott módszerek önálló fejezetben történő ismertetésétől eltekintünk. A cikkben tárgyalt projekteken kívül a régióra párhuzamosan született egyéb eredményeket diszkussziós céllal említjük.

\section{Az ásványfázisok, felszín alatti vizek és vízáramlási rendszerek megismerésére vonatkozó eredmények és értelmezésük}

\section{Ásványfázisok és fluidumzárványaik a miocén rendszerben}

A paleofluidumok összetételének, az ezekból kiváló ásványfázisok, ill. azok időbeli változásainak megismerése fejlődéstörténeti szempontból, valamint a budai barlangok kialakulása szempontjából egyaránt lényeges kérdés. A legjellemzőbb telérkitöltő ásványok a kalcit, barit, fluorit és a szulfidok, melyek közül a Budai-hegységben a kalcit dominál, a második leggyakoribb ásvány a barit. A fluorit mellett kisebb mennyiségben pirit, markazit, cinnabarit és egyéb szulfidásványok (cink-szulfid, metacinnabarit, galenit és elemi kén) is előfordulnak (GÁL et al. 2008, GYôRI et al. 2011, Poros et al. 2012).

A miocén korú repedéskitöltő kalcitból szénhidrogénés vizes fázisú zárványokat egyaránt azonosítottak (POROS et al. 2012), melyek spektroszkópos vizsgálata $\mathrm{CO}_{2}$ és $\mathrm{CH}_{4}$ jelenlétét mutatta ki mind a szénhidrogén, mind a vizes fázisban. Szénhidrogén-indikációk csak a központi régió zárványaiban voltak megfigyelhetôk, a déli paleorendszerben nem jelentkeztek. Mikrotermometriai vizsgálatok alapján a repedéskitöltő ásványok $80^{\circ} \mathrm{C}$-os fluidumból váltak ki (Poros et al. 2012). A zárványok szalinitása extrém alacsony $\left(<1,7 \mathrm{NaCl}_{\mathrm{eq}} \mathrm{wt} \%\right)$, csapdázódásuk 85 bar nyomáson történt (Poros et al. 2012). A miocéntôl fennálló hidrotermális rendszer fó ásványkiválásai időben változtak (ERőss et al. 2011b, Poros et al. 2010). A miocénre jellemző kalcit-, barit- és fluorit-kiválást a miocén végétől megjelenő fluorit, barit, dolomit és gipsz váltotta fel a travertínó-kiválások oldási maradékában (KOVÁCS-PÁLFFY \& FöLDVÁRI 2004, KELE 2009).

A telérkitöltések megismerése azért lényeges, mert számos barlang ezen miocén korú telérek mentén oldódott ki (GÁl et al. 2008, GYőRI et al. 2011, Poros et al. 2012). A kalcit, barit és fluorit kiválása ún. medence fluidumokból történt. Mikrotermometriás nyomásadatok alapján az ásványokban található primer zárvány bezáródása idején a karbonátot hozzávetőlegesen 800 m vastag fedő borította (Poros et al. 2012). A fluidumzárványokban jelenlévő szénhidrogén a középső-miocénben kifejlődő paleoáramlási rendszerben jelenlévő medenceeredetû, NaCl-os jellegû vizekhez és gázokhoz köthetô. A vizsgált repedéskitöltő ásványok nyomelem-összetétele azt jelzi, hogy a Ba, F, S,
$\mathrm{Fe}, \mathrm{Sr}, \mathrm{Hg}$ és $\mathrm{Cu}$ a szénhidrogénfázissal, valamint a $\mathrm{CO}_{2}$-vel együtt migrálhattak (Poros 2011). A fluidumzárványok szalinitása ugyanakkor arra utal, hogy a medence fluidumokat már ekkor számottevő mennyiségú beszivárgásból származó, azaz meteorikus eredetú karsztvíz hígította (Poros et al. 2012). A szpeleotémákban a pleisztocén végétôl az alacsony Mg-tartalmú kalcit, aragonit, gipsz vált dominánssá.

\section{Az ásványfázisok ${ }^{34}$ S értékei}

A kéntartalmú ásványok időbeli, trendszerú változásának, valamint a kén eredetének megértéséhez az ásványfázisokból mért ${ }^{34} \mathrm{~S}$-izotóp értékek nyújtottak támpontot ( $I$. táblázat, 2. ábra), melyek méréseink alapján a Budai-termálkarszt tágabb környezetére vonatkozóan széles spektrumon, $-32--38 \%$ o között mozognak (ERőss et al. 2011b, Poros et al. 2010).

A szulfáthordozó ásványok tekintetében a Budai-hegység kőfejtőiből és barlangjaiból származó baritminták ${ }^{34} \mathrm{~S}$ tartalma 22 - (38)\%o közötti értéktartományban változnak mind a központi (barit II minta, I. táblázat), mind a déli (barit I minta, I. táblázat) rendszerből származó minták esetében (ERőss et al. 2011b, Poros et al. 2010). A központi rendszerhez tartozó József-hegyi- és Szemlő-hegyi-barlangokból származó gipszminták ${ }^{34}$ S-értékei, $(-22--17 \%$ ) a Budai-hegység déli területén található Citadella-barlangból származó gipsszel összevetve $(2,3 \%$ ) jelentős eltérést mutatnak (I. táblázat). A Molnár János-barlangban képződő gipsz izotópértékei a központi rendszer száraz barlangjainak gipszkiválásához képest is számottevő negatív eltolódást mutatnak $(-32--27 \%$ ). A déli rendszerben a forrásbarlangokból származó gipsz kénizotóp értéke széles skálán változik, a Török-forrásra jellemző -1,6-10\%o értéktől egészen a Rákóczi-forrás -18\% értékéig. A Molnár Jánosbarlang Budai Márga Formációból származó piritje $-6,7 \%$ órtéket mutat (ERŐss et al. 2011b, Poros et al. 2010).

Az adatokból láthatjuk, hogy a baritásványokon mért értékek a központi rendszeren belül nem mutatnak jelentős szórást, a déli rendszerben is csak némileg kisebbek a központihoz viszonyítva (2. ábra). A déli rendszerre vonatkozóan a Citadella-barlang és a Török-forrás közel állnak egymáshoz, mely a kénforrás tekintetében közös genetikára utalhat. A Török-forrás néhány gipszmintája és a Rákócziforrás gipszkiválásának kénizotópértéke ugyanakkor jelentôs negatív eltolódást mutat. Ezt valószínúsíthetően az ezen barlangokban kimutatott mikrobiológiai hatásokkal magyarázhatjuk, mely az ásványkiválást és a kénizotópértékeket is befolyásolhatja (ANDA et al. 2015).

A központi rendszer száraz barlangjaiban és a vízzel kitöltött Molnár János-barlangban a gipszre kapott $\delta^{34} \mathrm{~S}$ értékek jelentôsen negatívabbak a déli rendszer recens gipszkiválásainak izotópértékeihez képest. Magyarázatként felmerülhet a pirit bakteriális oxidációja és az ennek hatására bekövetkező negatív irányú $\quad \delta^{34} S$-izotóp-eltolódás (ANDA et al. 2015, 2016). 
I. táblázat. Ásványkiválások $\delta^{34} \mathrm{~S}$ értékei

Table I. $\delta^{34}$ S isotope values of mineral precipitations

\begin{tabular}{|c|c|c|c|c|c|c|c|}
\hline Név & Rövidités & Rendszer & $\delta^{34} \mathrm{~S}_{\mathrm{CD}}(\% 0)$ & Ásvány & Kiválás kora & Mérés helye & $\begin{array}{c}\text { Mérési hiba } \\
(\%)\end{array}$ \\
\hline Kis-Sváb-hegy & KSh & központi & 30,1 & barit II & paleo & ENI & $\pm 0,3$ \\
\hline Lapos kőfejtő & $\mathrm{Lk}$ & központi & 25,3 & barit II & paleo & ENI & $\pm 0,3$ \\
\hline Molnár János -barlang 1 & $\mathrm{MJb}$ & központi & 27,6 & barit II & paleo & ENI & $\pm 0,3$ \\
\hline Molnár János -barlang 2 & $\mathrm{MJb}$ & központi & 34,6 & barit II & paleo & Atomki & $\pm 0,5$ \\
\hline Molnár János -barlang 3 & $\mathrm{MJb}$ & központi & 38,1 & barit II & paleo & Atomki & $\pm 0,5$ \\
\hline Molnár János -barlang 4 & $\mathrm{MJb}$ & központi & 30,4 & barit II & paleo & Atomki & $\pm 0,5$ \\
\hline Molnár János -barlang 5 & $\mathrm{MJb}$ & központi & 35 & barit II & paleo & Atomki & $\pm 0,5$ \\
\hline Józsefhegyi-barlang 1 & Jhb & központi & $-17,30$ & gipsz & paleo & Atomki & $\pm 0,5$ \\
\hline Józsefhegyi-barlang 2 & Jhb & központi & $-22,50$ & gipsz & paleo & Atomki & $\pm 0,5$ \\
\hline Józsefhegyi-barlang 3 & Jhb & központi & $-18,10$ & gipsz & paleo & Atomki & $\pm 0,5$ \\
\hline Józsefhegyi-barlang 4 & Jhb & központi & $-18,90$ & gipsz & paleo & Atomki & $\pm 0,5$ \\
\hline Józsefhegyi-barlang 5 & Jhb & központi & $-21,40$ & gipsz & paleo & Atomki & $\pm 0,5$ \\
\hline Szemlöhegyi-barlang 1 & Szhb & központi & $-19,20$ & gipsz & paleo & Atomki & $\pm 0,5$ \\
\hline Szemlöhegyi-barlang 2 & Szhb & központi & $-19,80$ & gipsz & paleo & ENI & $\pm 0,3$ \\
\hline Molnár János -barlang 6 & $\mathrm{MJb}$ & központi & $-32,3$ & gipsz & recens & ENI & $\pm 0,3$ \\
\hline Molnár János -barlang 7 & $\mathrm{MJb}$ & központi & $-27,40$ & gipsz & recens & Atomki & $\pm 0,5$ \\
\hline Molnár János-barlang 8 & $\mathrm{MJb}$ & központi & $-6,70$ & pirit & paleo & Atomki & $\pm 0,5$ \\
\hline Budaörs, Odvas-hegy & BöO & déli & 23,70 & barit I & paleo & ENI & $\pm 0,3$ \\
\hline Budaörs, Törökugrató & BöT & déli & 22,70 & barit I & paleo & ENI & $\pm 0,3$ \\
\hline Citadella-barlang & $\mathrm{Cb}$ & déli & 2,30 & gipsz & paleo & Atomki & $\pm 0,5$ \\
\hline Rákóczi-forrás & Rf & déli & $-18,00$ & gipsz & recens & ENI & $\pm 0,3$ \\
\hline Török-forrás 1 & Tf & déli & 10,10 & gipsz & recens & Atomki & $\pm 0,5$ \\
\hline Török-forrás 2 & $\mathrm{Tf}$ & déli & 8,70 & gipsz & recens & Atomki & $\pm 0,5$ \\
\hline Török-forrás 3 & $\mathrm{Tf}$ & déli & 5,80 & gipsz & recens & Atomki & $\pm 0,3$ \\
\hline Török-forrás 4 & $\mathrm{Tf}$ & déli & $-1,60$ & gipsz & recens & ENI & $\pm 0,3$ \\
\hline
\end{tabular}

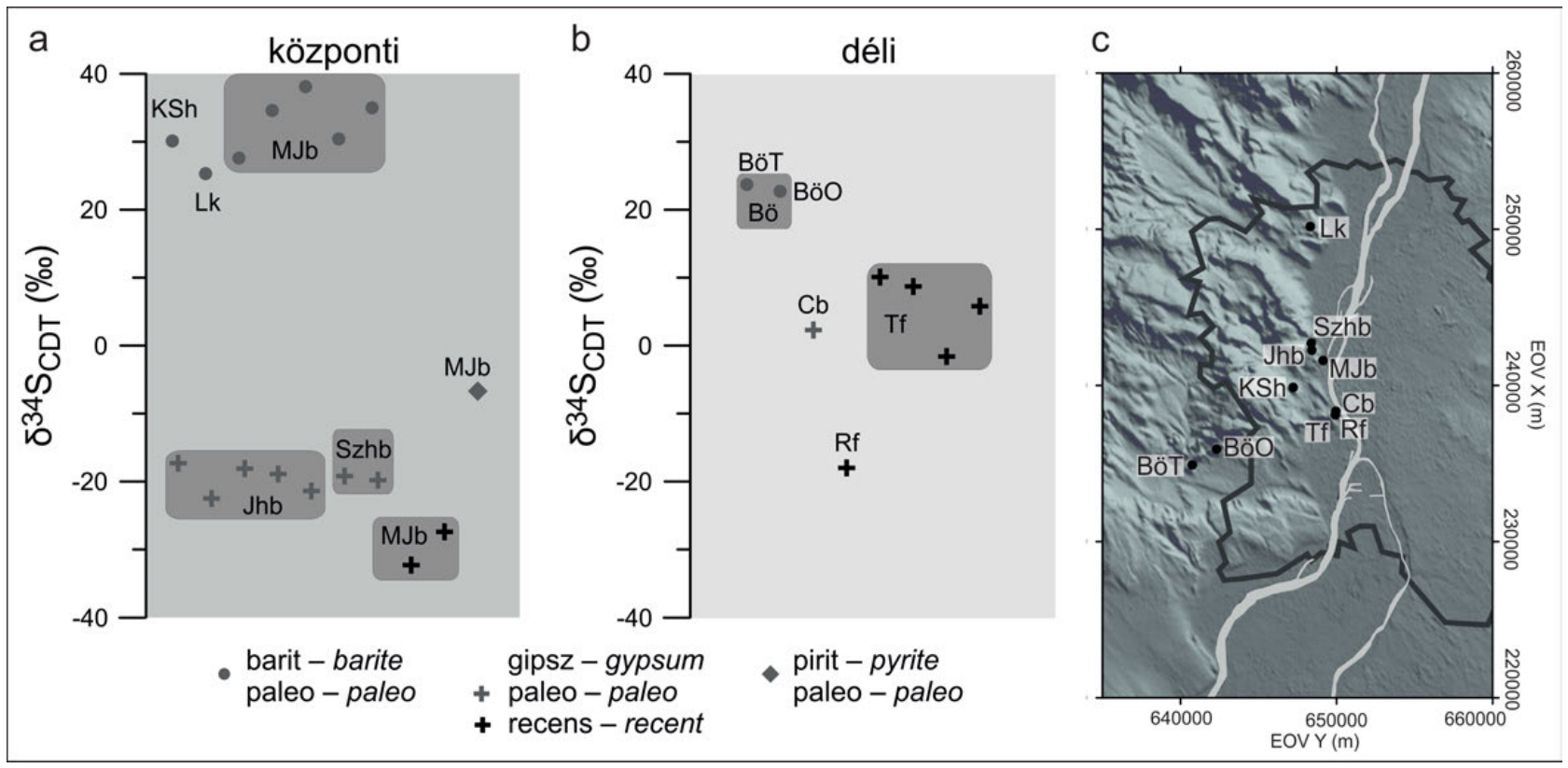

2. ábra. a) Ásványkiválások $\delta^{34} \mathrm{~S}$ értékei és tartományai a központi és a déli rendszerből származó minták elkülönítésével: KSh = Kis-Sváb-hegy, Lk = Lapos kőfejtő, MJb = Molnár János-barlang, Jhb = József-hegyi-barlang, Szhb = Szemlö-hegyi-barlang, Bö = Budaörs, BöO = Budaörs, Odvas-hegy, BöT = Budaörs, Törökugrató, $\mathrm{Cb}$ = Citadella-barlang, Rf = Rákóczi-forrás, Tf = Török-forrás (adatok forrása: Poros et al. 2010) (Mérés: Atomki és Eni (2010); három mérés átlagából kapott értékek, hiba: $\pm 3-5 \%$ ) b) A mintavétel helyszíneinek indextérképe (magyarázat: I. táblázat)

Figure 2. a) $\delta{ }^{34}$ S isotope values and ranges of mineral precipitations of the Central and Southern system: KSh=Kis-Sváb Hill, Lk=Lapos quarry, MJb = Molnár János Cave, Jhb = József-hegy Cave, Szhb = Szemlö-hegy Cave, Bö = Budaörs, BöO = Budaörs, Odvas-hegy, BöT = Budaörs, Törökugrató, Cb = Citadella Cave, Rf = Rákóczi Spring, Tf--Török Spring (data source: Poros et al. 2010), Rk=Ráckeve (data source: Poros et al. 2010) (Analysis: Atomki and Eni (2010); average values of three measurements, the error of analysis: $\pm 3-5 \%$ ) b) Index map of sample locations (explanation: Table I) 


\section{A Rózsadomb és a Gellért-hegy elóterében megcsapolódó vizek komponensei}

A Budai-termálkarszt kutakban, ill. forrásokon keresztül felszínre jutó vizeiben a központi és déli rendszerek különbségei a vízkémiai összetételben és radionuklid tartalomban is nyomonkövethetők. ERôss (2010), valamint ERŐSs et al. (2012b) — a BTK két alrendszerének termálkútjai és forrásai fő- és nyomelem-összetételére, valamint a radionuklidokra kiterjedő - elemzésével, átfogó képet adott a BTK déli és központi rendszerének megcsapolódási területein megmutatkozó különbségekről. Geokémiai PHREEQC — modellezés alapján a Rózsadomb (központi rendszer) esetében két keveredési szélsô tag mutatható ki, egy meteorikus és egy hidrotermális összetevő (ERőss et al. 2012b), melyek kémiai összetételét a II. táblázat foglalja össze. A központi rendszerben e két összetevő különböző arányú keveredésével kell számolni (ERőss 2010, ERôSS et al. 2012b). Ugyanakkor a Gellért-hegy előterében felszínre jutó források kémiai összetételében és hőmérsékletében nincs számottevő különbség. Az itt megcsapolódó vizekben — a radionuklidok alapján — csak hidrotermális összetevő azonosítható (ERôss et al. 2012b).

A két területre levezetett hidrotermális komponensek fizikai-kémiai paramétereinek, valamint radionuklid-tartalmának összevetése révén kiderült, hogy a kationokat tekintve a Rózsadomb forrásai és kútjai nagyobb $\mathrm{Na}^{+}$, míg a Gel-

II. táblázat. A meteorikus és a hidrotermális vizek (keveredési szélsőtagok) PHREEQC modellezéssel levezetett fizikai-kémiai paraméterei, valamint azok levezetett radionuklid-tartalma a Rózsadomb területére (ERőss et al. \{2012\} táblázata, Table 4) kiegészítve ERőss (2010) dolgozatából származó adatokkal, valamint a Gellért-hegy előterére a kutakban és forrásokban mért ugyanezen adatok átlagértékei (ERőss \{2010\} adatai alapján)

Table II. Characterization of the Rózsadomb and Gellért Hill discharge areas. Physicochemical parameters and radionuclides of meteoric and hydrothermal components (mixing end members) on the basis of PHREEQC modelling for the Rózsadomb area (Table 4 of ERÖSS et al. 2012b, complemented by the data of ERÖSS 2010; and on the basis of average values of springs and wells for the foothills of the Gellért Hill (after the data of ERöSS 2010)

\begin{tabular}{|c|c|c|c|c|}
\hline & & \multicolumn{2}{|c|}{ Rózsadomb } & \multirow{2}{*}{$\begin{array}{l}\text { Gellért-hegy } \\
\text { Gellért Hill }\end{array}$} \\
\hline & & $\begin{array}{l}\text { Meteorikus } \\
\text { Meteoric }\end{array}$ & $\begin{array}{l}\text { Hidrotermás } \\
\text { Hydrothermal }\end{array}$ & \\
\hline $\mathrm{T}$ & ${ }^{\circ} \mathrm{C}$ & 12,0 & 76,5 & 42,7 \\
\hline TDS & $\mathrm{mg} / \mathrm{l}$ & 775,0 & 1440,0 & 1617,0 \\
\hline $\mathrm{pH}$ & $\mathrm{mg} / \mathrm{l}$ & 7,0 & 6,0 & 6,5 \\
\hline $\mathrm{Na}^{+}$ & $\mathrm{mg} / \mathrm{l}$ & 9,0 & 180,5 & 169,5 \\
\hline $\mathrm{K}^{+}$ & $\mathrm{mg} / \mathrm{l}$ & 2,0 & 20,6 & 20,6 \\
\hline $\mathrm{Ca}^{2+}$ & $\mathrm{mg} / \mathrm{l}$ & 115,5 & 163,2 & 187,0 \\
\hline $\mathrm{Mg}^{2+}$ & $\mathrm{mg} / \mathrm{l}$ & 44,5 & 33,4 & 57,3 \\
\hline $\mathrm{Cl}$ & $\mathrm{mg} / \mathrm{l}$ & 16,0 & 202,0 & 169,3 \\
\hline $\mathrm{HCO}_{3}$ & $\mathrm{mg} / \mathrm{l}$ & 445,0 & 576,0 & 618,0 \\
\hline $\mathrm{SO}_{4}^{2-}$ & $\mathrm{mg} / \mathrm{l}$ & 113,0 & 207,5 & 352,7 \\
\hline${ }^{226} \mathrm{Ra}$ & $\mathrm{mBq} / \mathrm{l}$ & 0,0 & 503,9 & 594,8 \\
\hline${ }^{234+238} \mathrm{U}$ & $\mathrm{mBq} / \mathrm{l}$ & 74,0 & 0,0 & 15,5 \\
\hline $\begin{array}{c}\text { szabad } \mathrm{CO}_{2} \\
\text { free } \mathrm{CO}_{2}\end{array}$ & $\mathrm{mg} / \mathrm{l}$ & 52,0 & 228,7 & 156,7 \\
\hline $\mathrm{CH}_{4}$ & $\mathrm{mg} / \mathrm{l}$ & 0,0 & 0,5 & 0,0 \\
\hline $\mathrm{H}_{2} \mathrm{SiO}_{3}$ & $\mathrm{mg} / \mathrm{l}$ & 9,0 & 62,0 & 35,9 \\
\hline $\mathrm{S}^{2-}$ & $\mathrm{mg} / \mathrm{l}$ & 0,2 & 0,7 & 0,6 \\
\hline
\end{tabular}

lért-hegy forrásai és kútjai nagyobb $\mathrm{Ca}^{+}$és $\mathrm{Mg}^{2+}$-tartalommal bírnak. Az anionokat tekintve a Rózsadomb esetén magasabb, a Gellért-hegy megcsapolódási területén alacsonyabb $\mathrm{Cl}^{-}$-tartalom, valamint a szulfáttartalom fordított irányú különbsége figyelhető meg. A két terület jellegzetességei közötti további különbség a szabad $\mathrm{CO}_{2}$-tartalomban jelentkezik. A legnagyobb $\mathrm{CO}_{2}$-tartalommal a központi rendszer hidrotermális összetevője rendelkezik, melynek egyúttal legalacsonyabb a pH-ja. $\mathrm{A} \mathrm{CH}_{4}$ jelenléte kizárólag a központi rendszer hidrotermális komponensében volt kimutatható, melyben a $\mathrm{H}_{2} \mathrm{~S}$-hez kötődő szulfidtartalom is némileg nagyobb (ERőss 2010). Továbbá a központi rendszer vizeiben a Gellért-hegyi értéket jelentősen meghaladó kovasavtartalom figyelhető meg.

\section{A vizekben mért $\delta^{34} S$ izotóp értékek}

A budapesti termálvizek oldott szulfátjának $\delta^{34} \mathrm{~S}$ elemzése a kénizotópok ásványparagenezisekben megmutatkozó térbeli különbségek, valamint a központi és déli rendszer vizeiben tapasztalt különbségek magyarázata szempontjából egyaránt indokolt. Az ERőss (2010) dolgozatában szereplő $\delta^{34} S$ és szulfáttartalomra vonatkozó adatokat az értelmezés érdekében kiegészítettuik SzABó et al. (2009) munkájából rendelkezésre álló adatokkal (III. táblázat, 3. ábra).

A szulfáttartalom alapján a két rendszer vizei egyértelmúen elkülönülnek. A termálkutakat és a termálforrásokat tekintve a $\delta^{34}$ S-tartalomban különbség nem figyelhető meg (3. ábra). A langyos források szulfátja a központi rendszer termálvizeinek alsó tartományában marad, viszont $\delta^{34} \mathrm{~S}$ tartalma eltér a termálkutak és termálforrások értékétől. A központi rendszer termálkútjaira lineáris összefüggés figyelhető meg a szulfáttartalom és a $\delta^{34} S$ között. Ez nem mondható el a déli rendszer termálkútjaira és forrásaira, ott a szulfáttartalomnak nincs egyértelmú összefüggése a $\delta^{34} S$ értékekkel. Ugyanakkor területi trend figyelhető meg a $\delta^{34}$ S-tartalomban. A dél-pesti termálkutakat jellemzik a legpozitívabb értékek, a Gellért-hegy termálkútjainak adatai némileg alacsonyabbak, míg a termálforrások $\delta^{34} S$ értékei jellemzően némi negatív eltolódást mutatnak ugyanezen terület termálkútjainak vizéhez képest.

\section{A megcsapolódási terület tágabb környezetében található források bevonása az értékelésbe}

A központi és déli kutakra és forrásokra szorítkozó elemzéseken túl a vizsgálatokat a BTK tágabb környezetére is kiterjesztettük. Ehhez a Dunántúli-középhegység ÉK-i részén található kataszterezett források (IzÁPY 2002) 1960 előtti archív adatainak klaszterezési eredményeit használtuk (4. ábra), lehetővé téve, hogy az áramlási rendszereket az intenzív bányavíztelenítés előtti, mintegy természetes állapotban tanulmányozhassuk (ALFÖLDI \& KAPOLYI 2007). A vizsgálatok hipotézise szerint a források a felszín alatti vízáramlási pályák végpontjai (MÁDL-SzŐNYI \& TóTH Á. 2015). Így azok nemcsak a megtett utat, de a tápláló áramlási rendszert is jellemzik, beleértve azok hierarchizáltságát 
III. táblázat. Kutakban és forrásokban mért $\delta^{34} \mathrm{~S}$, hömérséklet és szulfáttartalom a központi és déli rendszer, a termálkút és forrás, valamint a déli rendszeren belül a dél-pesti, gellért-hegyi területek elkülönitésével. Adatok forrása: ERőss (2010), mérést végezte: Atomki (2010) három mérés átlagából kapott értékek, hiba: $\pm 5 \%$, továbbá SzABó et al. (2009)

Table III. $\delta^{34} \mathrm{~S}$ temperature and sulphate of wells and springs of the Central and Southern system showing different regions. Data source: ERöss 2010, measured by Atomki (2010), average values based on three measurements, error: $\pm 5 \%$; and SZABÓ et al. 2009, respectively

\begin{tabular}{|c|c|c|c|c|c|c|c|}
\hline Név & Rövidités & $\begin{array}{c}\delta^{34} S_{\mathrm{cor}} \\
(\% 0)\end{array}$ & $\begin{array}{l}\text { Höm. } \\
\left({ }^{\circ} \mathrm{C}\right)\end{array}$ & $\begin{array}{l}\mathrm{SO}_{4}^{2-} \\
(\mathrm{mg} / \mathrm{l})\end{array}$ & Rendszer & Megjegyzés & Hivatkozás \\
\hline Széchenyi II. kút & SzII & 17,18 & 76,80 & 195 & központi & termálkút & SzABó et al. 2009 \\
\hline Széchenyi I. kút & SzI & 17,72 & 53,00 & 192 & központi & termálkút & SzABó et al. 2009 \\
\hline Lukács IV. kút & LIV & 11,63 & 52,50 & 161 & központi & termálkút & SzABó et al. 2009 \\
\hline Lukács V. kút & LV & 10,28 & 50,90 & 120 & központi & termálkút & SZABó et al. 2009 \\
\hline Paskál kút & $\mathrm{Pa}$ & 13,35 & 67,70 & 148 & központi & termálkút & SzABó et al. 2009 \\
\hline Magda kút & Ma & 16,12 & 69,00 & 202 & központi & termálkút & SzAвó et al. 2009 \\
\hline Margitsziget, IV. kút & MszIV & 9,68 & 38,10 & 120 & központi & termálkút & SzABó et al. 2009 \\
\hline Margitsziget, III. kút & MszIII & 10,19 & 37,80 & 126 & központi & termálkút & SzABó et al. 2009 \\
\hline Lukács Boltiv-forrás & $\mathrm{Bf}$ & $-4,91$ & 22,00 & 139 & központi & langyos forrás & SZABó et al. 2009 \\
\hline Lukács Római-forrás & LRf & $-5,66$ & 20,80 & 140 & központi & langyos forrás & SzABó et al. 2009 \\
\hline Lukács Török-forrás & LTf & $-3,60$ & 23,90 & 132 & központi & langyos forrás & Szabó et al. 2009 \\
\hline Csepel II. kút & Cs & 15,61 & 45,20 & 321 & déli & dél-pesti termálkút & SzABó et al. 2009 \\
\hline Kvassay kút & K & 11,65 & 46,20 & 337 & déli & dél-pesti termálkút & SzABó et al. 2009 \\
\hline Pesterzsébet kút & $\mathrm{Pe}$ & 11,32 & 41,80 & 331 & déli & dél-pesti termálkút & SzABó et al. 2009 \\
\hline Dunasétány kút & Ds & 10,10 & 45,30 & 366 & déli & dél-pesti termálkút & ERőss 2010 \\
\hline Rudas Juventus kút & RJ & 9,00 & 44,60 & 379 & déli & $\begin{array}{l}\text { Gellért-hegy elötere } \\
\text { termálkút }\end{array}$ & ERÖSs 2010 \\
\hline GT-III kút & $\mathrm{Gt}$ & 7,80 & 42,50 & 337 & déli & $\begin{array}{c}\text { Gellért-hegy elötere } \\
\text { termálkút }\end{array}$ & ERöss 2010 \\
\hline R-XIV kút & $\mathrm{R}$ & 7,40 & 43,20 & 289 & déli & $\begin{array}{c}\text { Gellért-hegy elötere } \\
\text { termálkút }\end{array}$ & ERöss 2010 \\
\hline Ősforrás & Ôf & 8,50 & 37,30 & 375 & déli & termálforrás & ERöss 2010 \\
\hline Rudas Török-forrás & RTf & 7,50 & 35,20 & 333 & déli & termálforrás & ERöss 2010 \\
\hline Rudas Mátyás-forrás & RMf & 7,10 & 37,00 & 299 & déli & termálforrás & ERöss 2010 \\
\hline $\begin{array}{l}\text { Rudas Diana Hygieia- } \\
\text { forrás }\end{array}$ & DHf & 7,50 & 31,40 & 332 & déli & termálforrás & ERöss 2010 \\
\hline Rác-Kis-forrás & RKf & 7,10 & 35,70 & 355 & déli & termálforrás & ERőSs 2010 \\
\hline Rác-Nagy-forrás & RNf & 7,30 & 37,40 & 331 & déli & termálforrás & ERöss 2010 \\
\hline
\end{tabular}

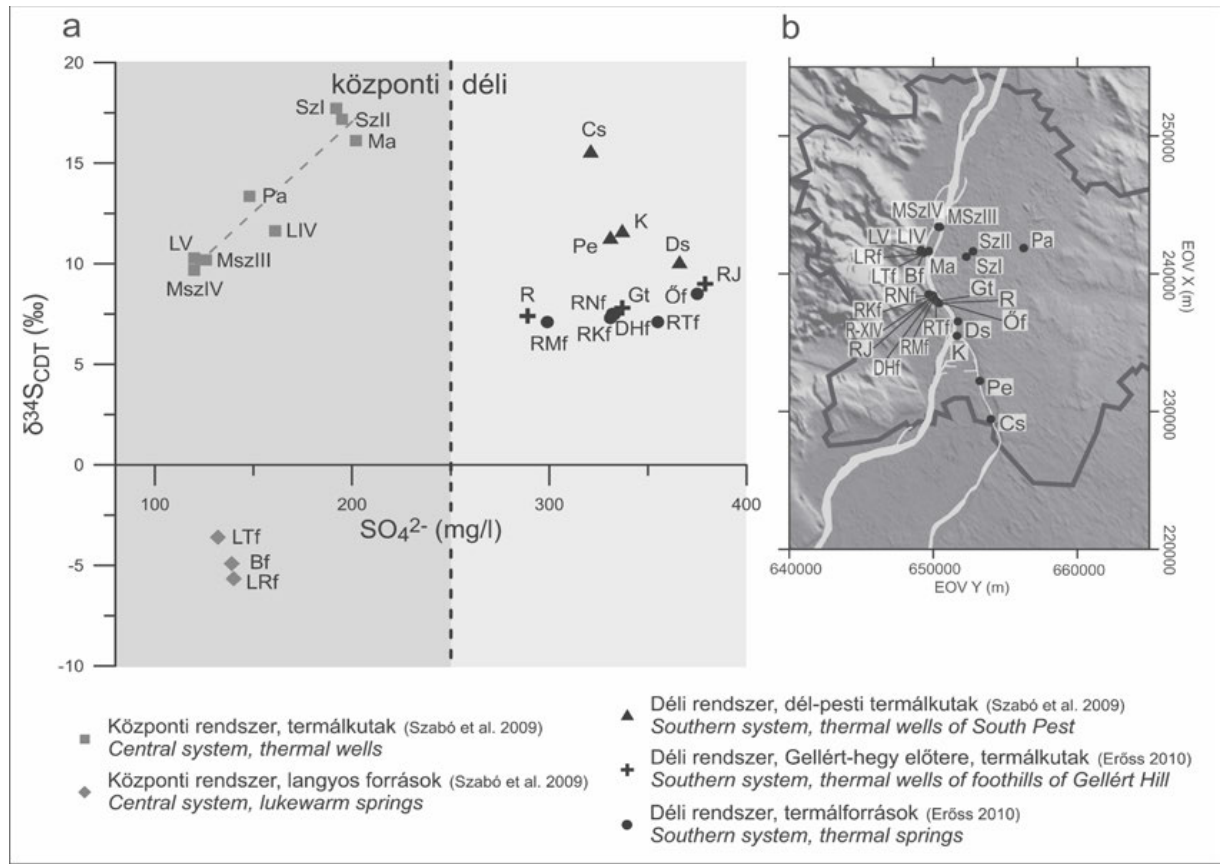

3. ábra. Kutakban és forrásokban mért $\delta^{34} \mathrm{~S}$ értékek a szulfáttartalom függvényében.

Az ábrán szereplő kutak és források neveinek röviditései: $\mathrm{Msz}=$ Margitsziget, $\mathrm{L}=$ Lukács, $\mathrm{Pa}=$ Paskál, $\mathrm{Ma}=\mathrm{Magda}, \mathrm{Sz}=$ Széchenyi, $\mathrm{Cs}=$ Csepel, $\mathrm{K}=$ Kvassay, $\mathrm{Pe}=$ Pesterzsébet, $\mathrm{R}=$ Rudas, $\mathrm{Gt}=$ Gellért-táró, $\mathrm{Ds}=$ Dunasétány, $\mathrm{RJ}$ = Juventus, $\mathrm{RMf}=$ Mátyás-forrás, $\mathrm{RNf}=$ Rác-Nagy- forrás, $\mathrm{RKf}=$ Rác-Kis- forrás, $\mathrm{RTf}=$ Rudas Török-forrás, Öf = Ösforrás, $\mathrm{DHf}=$ Diana-Hygeia-forrás, LTf = Lukács Török-forrás, $\mathrm{Bf}=$ Lukács Boltiv-forrás, $\mathrm{LRf}$ = Lukács Római-forrás (adatok: III. táblázat). Római számok jelzik a kutak sorszámát

Figure 3. $\delta^{34} S$ vs. sulphate plot of water samples of wells and springs.

Abbreviations of data points: $M s z=$ Margitsziget, $L=$ Lukács, $P a=$ Paskál, $M a=$ Magda, $S z=$ Széchenyi, $C s=C$ Csepel, $K=$ Kvassay, $P e=$ Pesterzsébet, $R=$ Rudas, Gt $=$ Gellért tunnel, $D s=$ Dunasétány, $R J=J u v e n t u s, R M f=$ Mátyás Spring, $R N f=$ Rác-Nagy Spring, $R K f=$ RácKis Spring, $R T f=$ Rudas Török Spring, Ö $=$ Ös Spring, $D H f=$ Diana-Hygeia Spring, $L T f=$ Lukács Török Spring, $B f=$ Lukacs Boltiviv Spring, $L R f=$ Lukács Római Spring (data source: Table III). Roman numbers denote the identification number 
(Pentecost 2005, Tóth J. 2009). Ebből a szempontból kiemelkedó a fakadási szint, hiszen domborzati hajtóeró esetén - a hipotézis értelmében — összefügg az áramlási rendszerek rendúségével (То́тн J. 2009). Kérdés, hogy a fakadási szint mutat-e szisztematikus kapcsolatot a források egyéb — hőmérsékleti, kémiai és hozam - jellemzőivel. Ennek megválaszolására a Dunántúli-középhegység egészére hierarchikus klaszteranalízist végeztünk (BODOR et al. 2015), melynek eredményeként a régió egészére a források hat, egyértelmúen elkülönülő csoportot alkottak. E csoportokat kétdimenziós stacioner vízáramlási szimuláció alapján regionális, köztes és helyi áramlásokhoz kötöttük (MádL-SzŐNYI \& TóTH Á. 2015). Ezen eredményt a BTK tágabb környezetében található negyven forrás értékelésére használtuk fel, melyek előzetes vízáramlási rendszerbe történó illeszkedése az 1. ábrán követhetô. A vizsgált negyven forrás fakadási szintjének tengerszint feletti magasságát az 1960 elő́tti kloridtartalom, hômérsékletés forráshozamadatok mediánjának függvényében ábrázoltuk, a források regionális értékelésen alapuló vízáramlási rendszerbe történô besorolásával együtt (helyi, köztes és regionális) (4. ábra).

A forráskilépési pont tengerszint feletti magassága tekintetében a helyi források egyértelmúen elkülönülnek, ugyanakkor a termál-és a langyos források között csak igen kis különbség jelentkezik. A legalacsonyabb tengerszint feletti magasságon a regionális áramláshoz köthető termálforrások fakadnak. A kloridtartalom tekintetében a helyi és köztes áramlásokhoz köthető források adatai közel azonos értéktartományban mozognak $(<40 \mathrm{mg} / \mathrm{l})$, ugyanakkor a regionális áramláshoz köthetô források kloridtartalma szignifikánsan nagyobb $(80-170 \mathrm{mg} / \mathrm{l})$. A forráskilépési pont tengerszint feletti magassága szerinti hőmérsékleteloszlás egyértelmú elkülönülést mutat a hideg, $\left(<15^{\circ} \mathrm{C}\right)$, langyos $\left(20-28^{\circ} \mathrm{C}\right)$ és termál $\left(38-58^{\circ} \mathrm{C}\right)$ források között. A köztes áramlásokhoz köthető források rendelkeznek a legnagyobb vízhozammal. A regionális termálforrások vízhozama nagyságrendileg a helyi hideg források és a langyos források között mozog (MÁDL-SzÓNYI \& TóTH Á. 2015).

A NaCl-jellegú medence fluidumok hozzájárulásával a regionális áramlások esetében számolhatunk. Ezek a meteorikus eredetú hidrotermális vizek kémiai jellemzőit módosítják, ill. olyan elemekkel gazdagítják összetételét, melyek a NaCl-os jellegú vízhez köthetóek. A köztes áramlásokhoz kapcsolható langyos vizek és a helyi rendszerekhez köthető hideg vizek egyaránt meteorikus eredetúek, ugyanakkor a vizsgálatok alapján fakadási szintjükben, hőmérsékletükben és vízhozamukban is elkülönülnek egymástól.
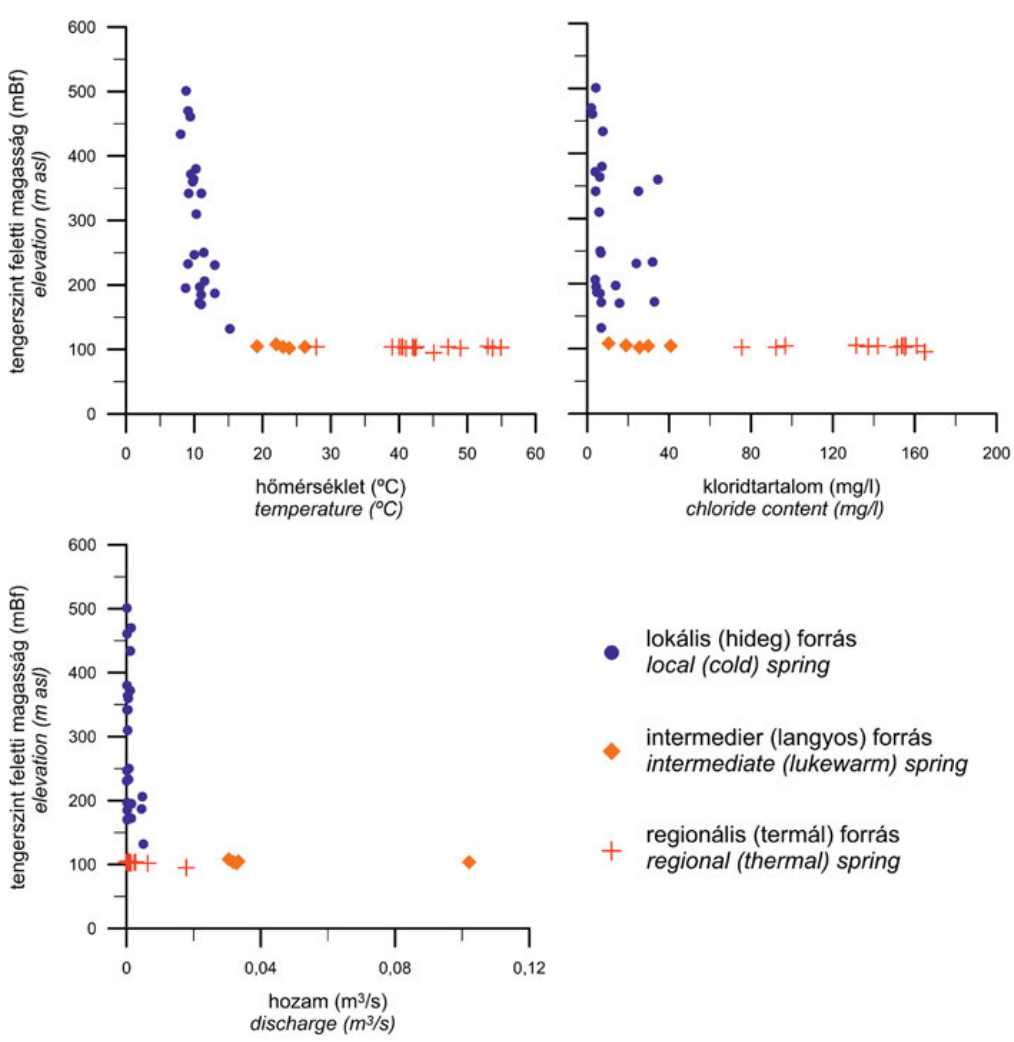

- lokális (hideg) forrás local (cold) spring

intermedier (langyos) forrás intermediate (lukewarm) spring

regionális (termál) forrás regional (thermal) spring

4. ábra. Forráscsoportok hőmérséklet-, vízhozam- és kloridtartalom-fakadási szint diagramokon ábrázolva (MÁDL-SzŐNYI \& TóTH Á. 2017 alapján). A Dunántúli-középhegység forrásaira elvégzett hierarchikus klaszteranalízis eredményéből ábrázolva (BODOR et al. 2015)

Figure 4. Spring groups in the Buda Thermal Karst displaying on temperature, discharge and chloride content vs. elevation plots after MÁDL-SZÖNYI \& TÓTH Á. (2017). Groups are based on hierarchical cluster analysis for the springs of the Transdanubian Range (BODOR et al. 2015) 


\section{A megcsapolódási területek környezetének áramlási viszonyai}

Annak érdekében, hogy a függőleges áramlási irányokról információt nyerjünk, a kutakban mért nyugalmi vízszintek szisztematikus értékeléséhez ERHARDT et al. (2017) és ÖTvÖS et al. (2017) hidraulikai adataiból kiindulva két mélységszintközre potenciáltérképet szerkesztettünk, majd képeztuik a két potenciáltérkép különbségét (5. ábra).

A budai oldalon az ekvipotenciál vonalak lefutása egyértelmúen korrelál a domborzattal (ERHARDT et al. 2017, ÖTVÖs et al. 2017), mely a vízszintek magasságkülönbségei által vezérelt, gravitációs áramlási rendszerek jelenlétét jelzi. A felső, 100-50 mBf szintközre vonatkozó potenciáltérképen kirajzolódik a Duna megcsapoló hidraulikai jellege. Az alsó, 50-0 mBf szintközre vonatkozó potenciáltérképen a nyugatról kelet felé csökkenő ekvipotenciál vonalak a felszín alatti víz Duna alatti átáramlását jelzik (ERHARDT et al. 2017). A Duna megcsapoló szerepe ebben a mélységben nem követhető.

A Rózsadomb területén kb. -5 m-es potenciálkülönbség tapasztalható a mélyebb és sekélyebb szintközre jellemző hidraulikus emelkedési magasságok között, míg a Gellérthegy előterében a különbség ettől kisebb, <-5 m. Ezek $100>\mathrm{z}>50 \mathrm{mBf}(\mathrm{m}$ asl)
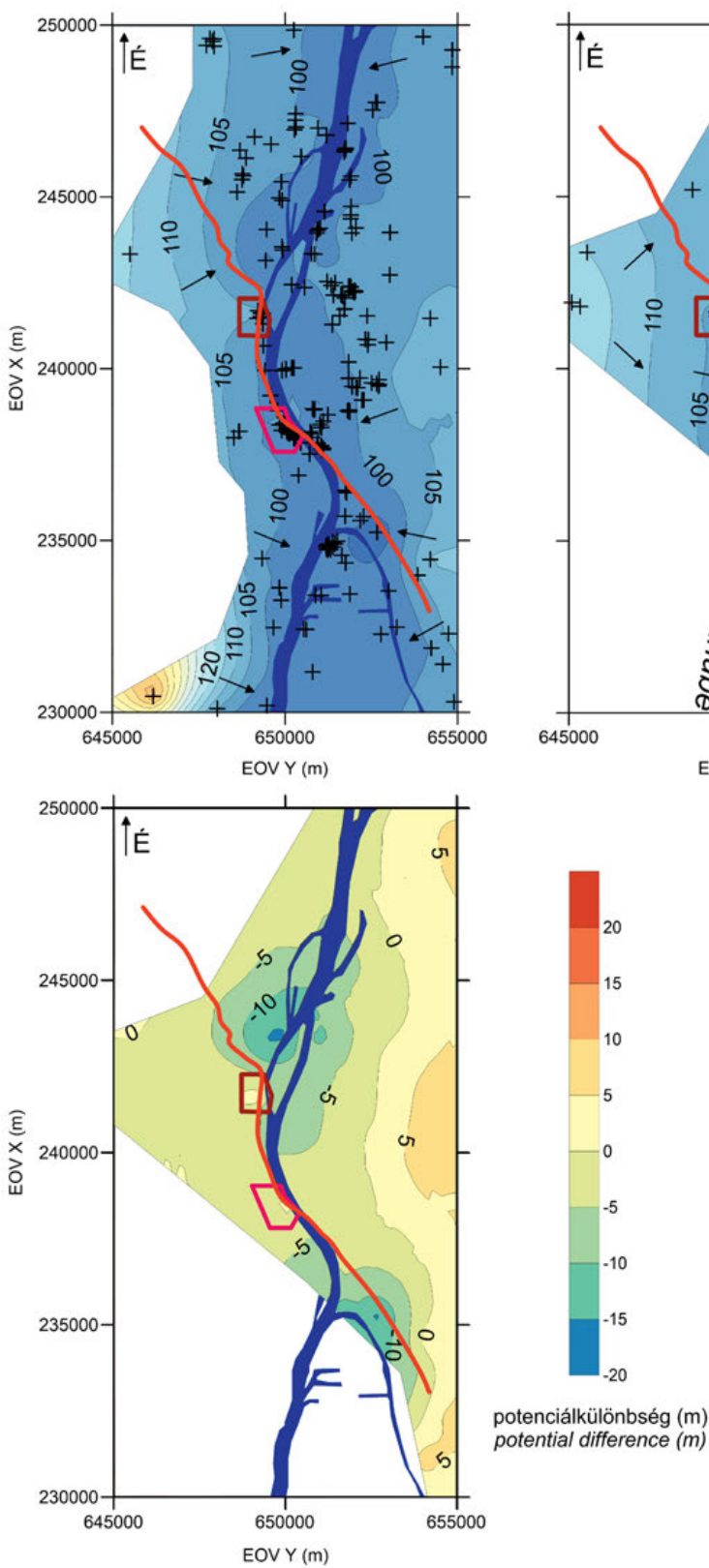

$50>\mathrm{z}>0 \mathrm{mBf}(\mathrm{m}$ asl)

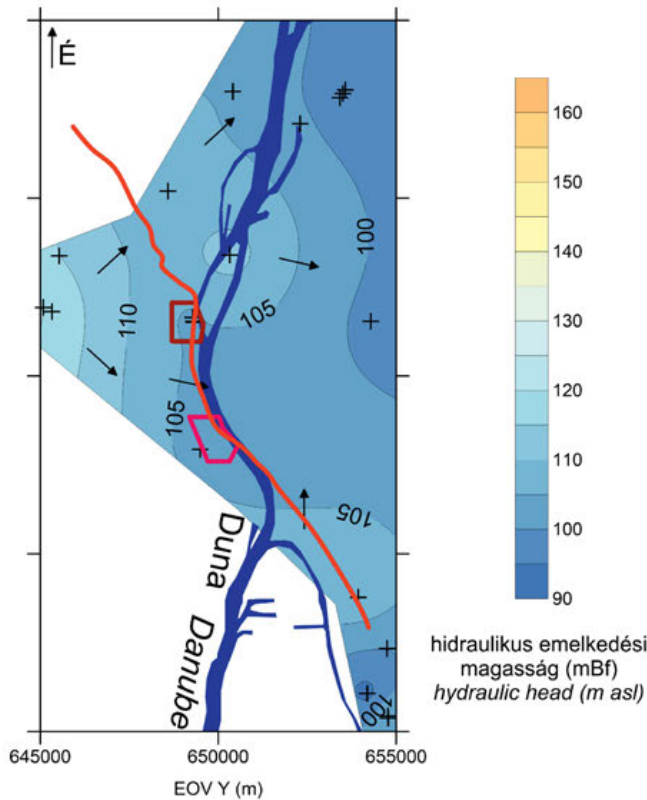

$$
\begin{array}{cl}
+\quad \begin{array}{l}
\text { hidraulikai adatpont } \\
\text { hydraulic data point }
\end{array} \\
-105-\begin{array}{l}
\text { ekvipotenciális vonal }(\mathrm{mBf}) \\
\text { equipotential line }(\mathrm{m} \text { asl) }
\end{array} \\
-5-\begin{array}{l}
\text { potenciálkülönbség izovonal }(\mathrm{m}) \\
\text { isoline of potential difference }(\mathrm{m})
\end{array} \\
\begin{array}{l}
\text { áramlási irány } \\
\text { direction of flow }
\end{array} \\
\square \quad \text { Rózsadomb } \\
\square \quad \begin{array}{l}
\text { Gellért-hegy } \\
\text { Gellért Hill } \\
\text { Északkeleti-peremvetö } \\
\text { Northeastern Margin Fault }
\end{array}
\end{array}
$$

5. ábra. Tomografikus potenciáltérkép, valamint a belölük szerkesztett potenciálkülönbség térkép (ERHARDT et al. (2017) adatainak felhasználásával)

Figure 5. Tomographic potential maps and potential difference map (data source: ERHARDT et al. 2017) 
alapján hidraulikailag is bizonyítható, hogy a vízáramlás függóleges komponense mindkét forrásterület esetében felfelé mutat, azaz feláramlás zajlik. A Dunától keletre ezzel szemben 5 m-es különbség jelenik meg, azaz a mélyebb szeletben kisebb, a sekélyebb zónában nagyobb hidraulikus emelkedési magasság jellemző, kifejezve a vizek a pesti oldal sziliciklasztos felszínközeli képződményeiben történő leáramlását. ERHARDT et al. (2017) és ÖTVÖs et al. (2017) rámutattak a területen húzódó északkeleti peremvető (5. ábra) torlasztó - függólegesen vezető, és vízszintesen záró - hidraulikai hatására és ezzel magyarázták a rózsadombi és a Gellért-hegy előterében található megcsapolódási területek elkülönülését. Ugyanakkor a mélyebb zóna potenciáleloszlása a Duna alatt átáramlást jelez, ami a peremvető vízszintes irányú torlasztó hatásának némileg ellentmond.

\section{A Budai-termálkarszt keleti határa}

Felmerült a kérdés, hogy keleti irányban meddig mozoghat a Duna alatt átáramló felszín alatti víz, ill. mi a forrásterülete a keleti irányból érkező, a Duna mentén feláramló víznek. A Gödöllői-dombság környezetére elvégzett, kutakban mért nyugalmi vízszintek és nyomásadatok értékelésén alapuló hidraulikai elemzés alapján a Pesti-síkság és a Gödöllői-dombság területe alatt a triász és eocén karbonátos víztartóban a felszín alatti víz kiáramlási terület felé történő mozgását nem túlnyomás okozza (MÁDL-SzŐNYI et al. 2015, 2017). A jelenlegi normál, ill. közel hidrosztatikus pórusnyomás-értékek inkább az alulnyomás felé tolódtak el. E jelenséget vízkivétel is előidézheti — melynek szerepe nem zárható ki —, de ennek egyértelmú hatását a kutak létesítéskori vízszintjei és azok időbeli változásának elemzése nem igazolta. Az alulnyomás kialakulásához ugyanakkor hozzájárulhatott a dombság 4 millió éve kezdődött kiemelkedése. A kiemelkedés eróziót idézett elő (RUSZKICZAYRÜDIGER et al. 2006), melynek hatására a vízzel telített kôzetváz egésze kôzetmechanikai értelemben nem egyensúlyi állapotba került. A Gödöllői-dombság paleogén és neogén vízfogó képződményeinek beszivárgást korlátozó hatása miatt a kiemelkedést nem követhette hatékony beszivárgás (MÁDL-SzŐNYI et al. 2015). A karbonátos képződmények a Szada-vetőtől K-DK irányban vastag fedőüledék alatt találhatók. A karbonátos víztartóból nyugat felől érkezô oldalirányú utánpótlódást a Szada-vetô korlátozza, mert síkjában az érkező víz, kelet felől kis hidraulikus vezetôképességú sziliciklasztos képződményekkel érintkezik. A Gödöllői-dombság vízfogó sziliciklasztos képződményein át szintén korlátozott a karbonátos víztartó utánpótlódása. INGEBRITSEN et al. (2006) nyomán e hatások együttesen vezethettek a karbonátos víztartó alulnyomásos helyzetéhez, és magyarázatként szolgálhatnak a Szada-vetőtől délkeletre, a Balaton-Tóalmás-vonal környezetében kimutatott alulnyomásos zóna kialakulására (6. ábra).

A Budai-termálkarszt K-DK-i hidraulikai határát domborzatilag vezérelt vízáramlást feltételezve — a dombság felszíni vízválasztója és az alulnyomásos zóna jelöli ki. Az alulnyomás közvetetten utal arra, hogy a Szada-vetőtől

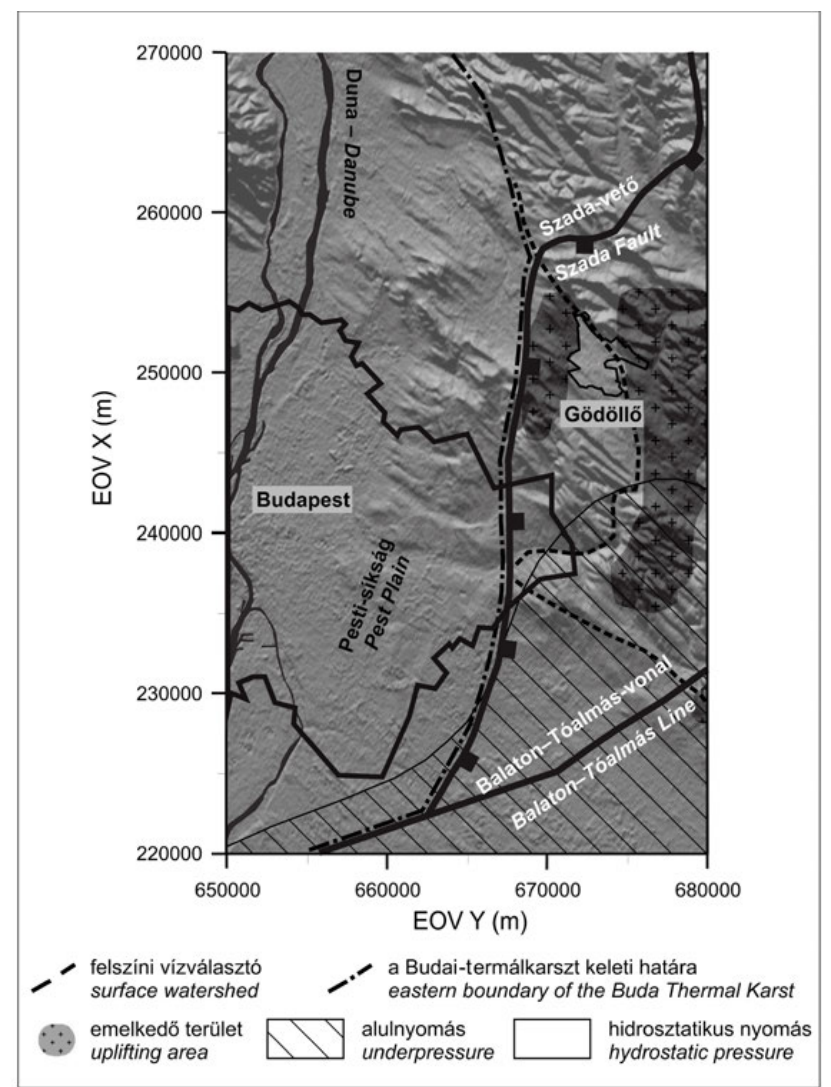

6. ábra. A BTK K-i lehatárolása a Gödöllői-dombság irányában (módosítva MÁDL-SzŐNYI et al. 2015). A főbb tektonikai elemek: HAAS et al. (2010), a kiemelkedő területek: RUSZKICZAY-RÜDIGER (2007), vízválasztó és a normálvalamint az alulnyomásos területek (MÁDL-SzŐNYI et al. 2017)

Figure 6. Delineation of eastern boundary of the BTK (Gödöllö Hills) (modified after MÁDL-SZÖNYI et al. 2015). Data source: tectonic lines - HAAS et al. (2010), uplifting areas - RUSZKICZAY-RÜDIGER (2007), surface watershed and areas of hydrostatic and underpressure - MÁDL-SZÖNYI et al. (2017)

K-DK irányban található karbonátos alaphegységi képződmények feltehetően nem állnak kapcsolatban a normál hidrosztatikus nyomásviszonyokkal rendelkezô Pesti-síkság alatti területekkel. A Budai-termálkarszt vízáramlási rendszerének feltételezhető keleti határát a 6. ábra szemlélteti.

\section{A medence fluidumok jelenléte a Budai- termálkarszt keleti félmedencéjében}

A BTK rendszerében azonosított medence fluidumokat korábbi szerzók a pesti oldal felől származtatták, ugyanakkor eredetükre vonatkozó magyarázattal nem szolgáltak (ERŐss et al. 2011a, b, MÁDL-SzŐNYI \& TóTH Á. 2015). Archív adatok alapján a kutakban mért $\mathrm{Cl}^{-}$-koncentráció a -500 és -1000 mBf közötti elevációtartományban a Dunától Budapest keleti határáig növekedő trendet mutat, és 18000 mg/l maximális értéket ér el. Mélyebben, -1000 mBf alatti mélységben - mely a karbonátos víztartót is érinti ugyanezen távolságban (a Dunától Budapest keleti határáig) a kloridkoncentráció mindössze $3000 \mathrm{mg} / \mathrm{l}$ értéket ér el (MÁDL-SzŐNYI \& TóTH Á. 2015, MÁDL-SZŐNYI et al. 2015, 2017). Ezt felismerve, a Gödöllői-dombság területére elvég- 
zett elemzések alapján ott, ahol az összes oldottanyag-tartalom (TDS) meghaladja a $3000 \mathrm{mg} / \mathrm{l}$ értéket, a terület alaphegységi karbonátos és fedőképződményeiben a vizek $\mathrm{Cl}^{-}$tartalma követi a TDS értékeket (MÁDL-SzŐNYI et al. 2015). Megvizsgálva a TDS eloszlását a Dunától keletre húzódó kivágatban, a medence fluidumok forrása levezethetô a Gödöllői-dombság területén található vizekből, a -500 és -1000 mBf közötti zónából, ahol az összes oldottanyagtartalom maximuma meghaladja a 40000 mg/l koncentrációértéket (7. ábra, a). Összevetve a -1000 mBf alatti koncentráció értékeket a kizárólag a karbonátos víztartóra szúrőzött kutakból származó koncentráció értékekkel, a medence fluidum forrása a karbonátos fedőben keresendő (7. $a ́ b r a, b, c$ ) (MÁdL-SzŐNYI et al. 2017). A NaCl-os ,,medence fluidum" az összes oldottanyag-tartalom maximuma alapján tehát a karbonátot fedő neogén és paleogén képződ-

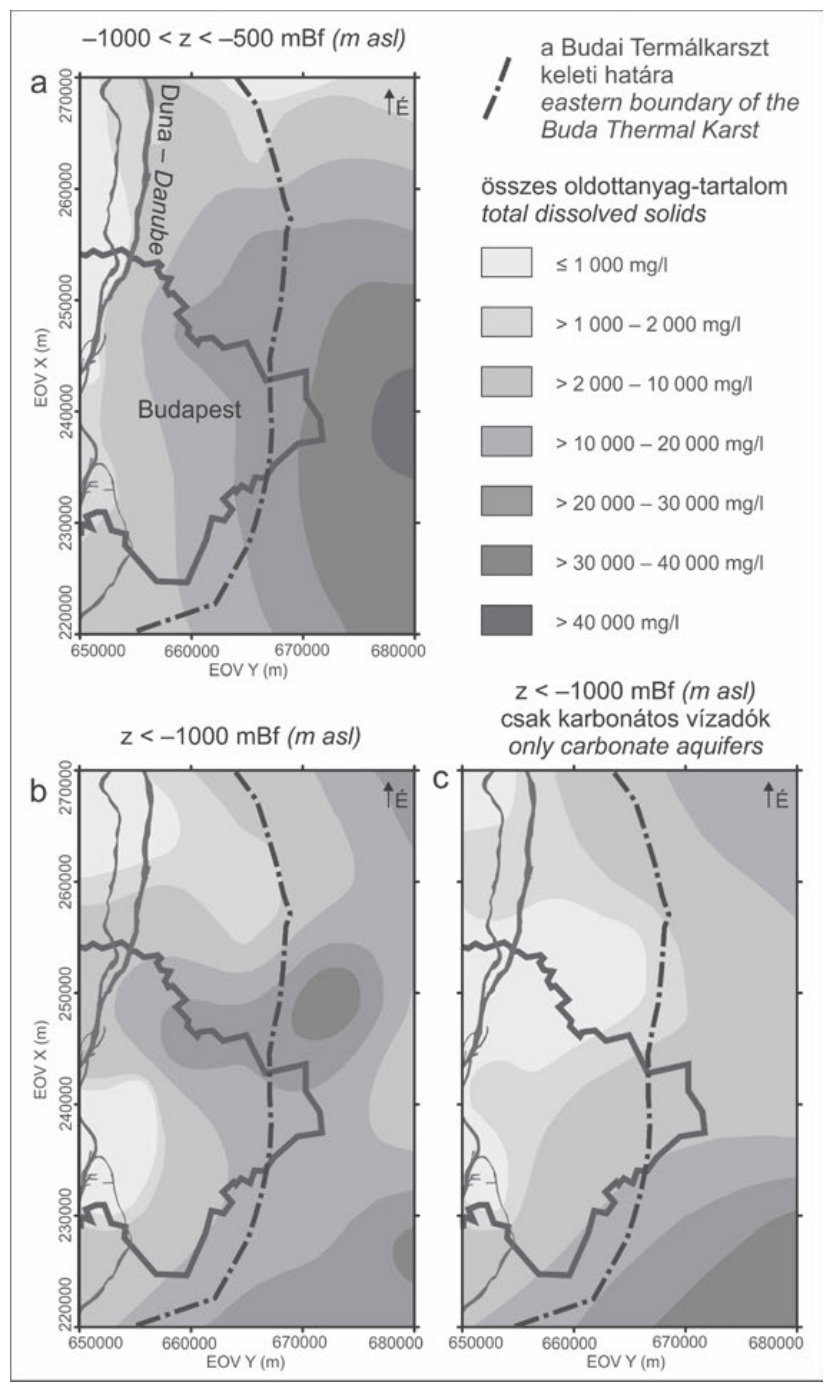

7. ábra. TDS-térkép a BTK Dunától K-re található területére: a) -500-(-1000) mBf között szürőzött kutak adataiból szerkesztve, b) - 1000 mBf alatt szürőzött valamennyi kútra szerkesztve, c) - $1000 \mathrm{mBf}$ alatt az alaphegységi karbonátos képződményekre szűrőzött kutak adataiból szerkesztve (MÁDL-SzŐNYI et al. 2017 térképei felhasználásával)

Figure 7. TDS map of the Eastern part of the BTK based on well data of a) -500 (-1000) $m$ asl elevation b) under $-1000 \mathrm{~m}$ asl c) under $-1000 \mathrm{~m}$ asl only for basement carbonates (after MÁDL-SZÖNYI et al. 2017) ményekhez kötődik. Ugyanakkor ilyen NaCl-os jellegú vizek koncentrált jelenléte a BTK Dunától nyugatra eső területein nem volt kimutatható.

További felmerülő, BTK-ra vonatkozó kérdés a vizek szulfáttartalmának eredete. Az archív kútadatok vízkémiai feldolgozásán alapuló elemzés azt mutatta, hogy 0 - (-500) mBf eleváció intervallumban a szulfátkoncentráció maximuma $<300$ mg/l értékkel Budapest területére esik, ugyanakkor mélyebben, $-500-(-1000)$ mBf leváció intervallumban, 1000 mg/l értékkel Budapesttôl DNy-ra található. A -1000 mBf alatti eleváció tartományban a koncentráció maximum értéke $600 \mathrm{mg} / \mathrm{l}$ értékre csökken és a Csepelsziget déli vonalában található (kívül esik az 1. ábra területén). A Dunától keletre esô területen hasonló szulfátanomália nem tapasztalható (MÁDLNÉ SzŐNYI et al. 2013).

\section{$2 D$ regionális léptékú áramlási- és hôtranszport- szimuláció a BTK déli rendszerében}

A felszín alatti vízáramlási kép, valamint a rendszerben zajló hőtranszport-folyamatok megismerésére a COMSOL Multiphysics szoftver (ZIMMERMAN 2006) segítségével kétdimenziós stacioner numerikus modellezést végeztünk. A regionális léptékú szimuláció során EPM (ekvivalens porózus média) megközelítést alkalmaztunk. A szerkezeti elemeket (normál vetők és oldaleltolódások) FoDOR et al. (1994) szerkezetföldtani adatai alapján vízvezető elemekként vettük figyelembe, melyhez a szoftver ,fracture flow” modulját használtuk. A szimulációhoz a Budai-termálkarszt területére készült reprezentatív földtani szelvényekből indultunk ki (FoDOR 2011 in MiNDSZENTY szerk. 2013). Tanulmányunkban a déli rendszert keresztező földtani szelvény mentén végzett vízáramlás-modellezés eredményeit mutatjuk be MÁDL-SzŐNYI \& TóTH Á. (2017) munkája nyomán (1. és 8. ábra).

A BTK területén előforduló földtani képződmények hidrosztratigráfiai besorolása, valamint a képződmények modellezéshez szükséges fizikai paramétereinek megállapítása MARTINECZ (2014) munkája alapján történt (8. ábra, a). A modell felsô határa a karsztvíz-, illetve a talajvízszint, mely a Duna vonalában rendelkezik a legkisebb értékkel. A nyugati határt CSEPREGI (2007) adataiból kiindulva konstans hidraulikus emelkedési magasságokkal jellemeztük. A K-i oldalon csökkenő hidraulikus emelkedési magasságokat adtunk meg a fedő réteg vastagságáig, alatta állandó hidraulikus emelkedési magasságokkal dolgoztunk MÁDL-SzŐNYI et al. (2015) tanulmánya alapján. Az alsó határt impermeábilisként kezeltük.

A hőtranszport-szimulációhoz a felső határt $11{ }^{\circ} \mathrm{C}$ középhőmérséklettel jellemeztük és LENKEY et al. (2002) nyomán $5{ }^{\circ} \mathrm{C} / 100 \mathrm{~m}$ geotermikus gradienst alkalmaztunk. Az oldalsó határokon keresztül a hőmérsékleti gradiens zérus. Az alsó határt $200{ }^{\circ} \mathrm{C}$-os kezdeti hômérsékletértékkel jellemeztük. A felhajtóerő szerepét nem vettük figyelembe a szimulációnál (8. ábra, a).

A modellezett szelvény a Zsámbéki-medencétől indul és a Gellért-hegytől délre a Pesti-síkságon át húzódik, ugyan- 


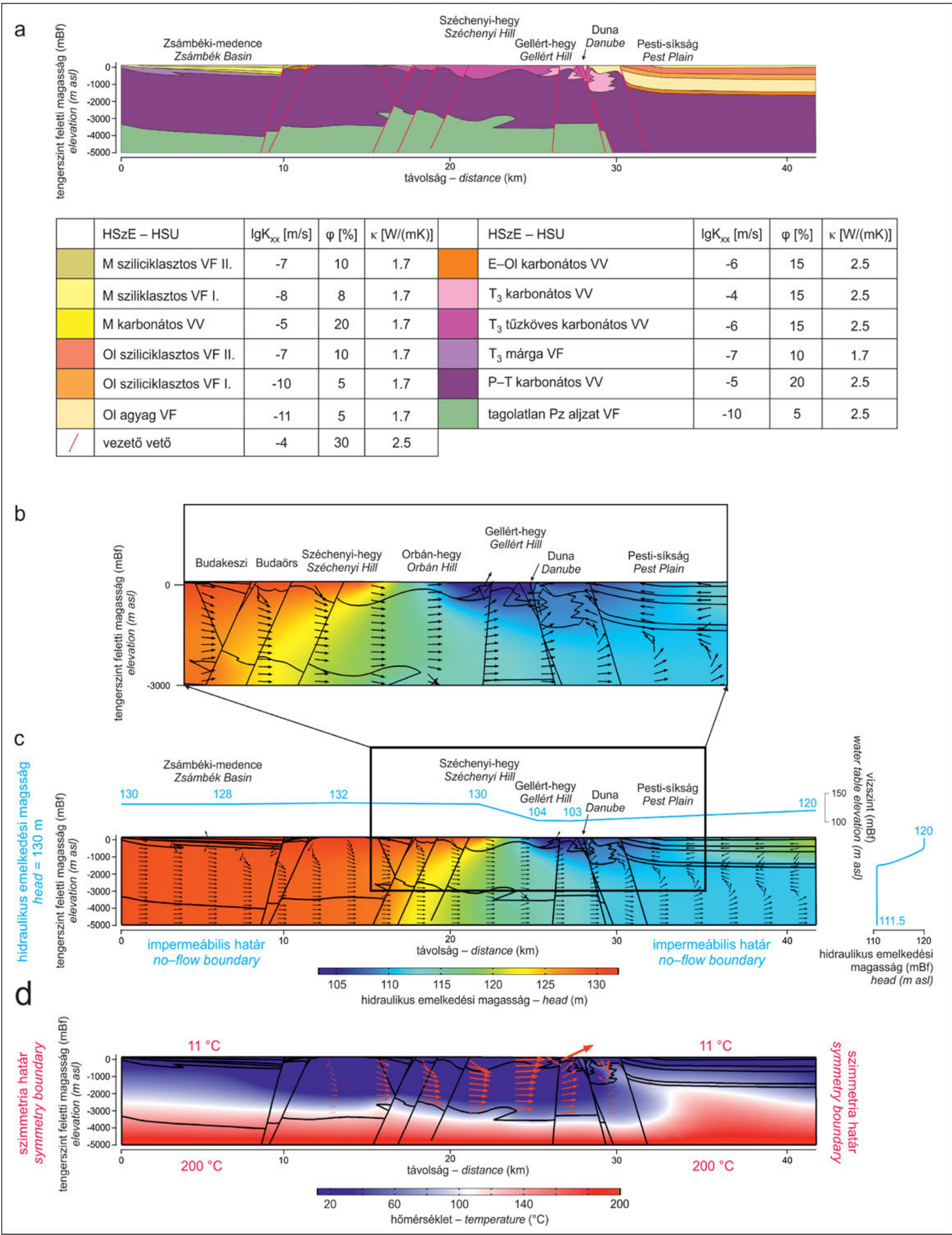

8. ábra. a) Hidrosztratigráfiai szelvény FODOR (in MINDSZENTY szerk. 2013) földtani szelvényéből levezetve, hidrosztratigráfiai kategóriákkal ellátva; b)-c) Szimulált áramlási kép a Gellért-hegyen keresztül egységes Darcy-sebesség vektorokkal; d) Szimulált hỏmérséklet eloszlás arányos Darcy-sebesség vektorokkal (MÁDL-SZŐNYI \& TóTH Á. 2017 nyomán) Szelvény nyomvonala: 1. ábra, A1-B1

Figure 8. a) Hydrostratigraphic section based on geologic section of FODOR (in MINDSZENTY ed. 2013); b-c) Simulated flow field across the Gellért Hill displaying uniform Darcy velocity vectors; $d$ ) simulated temperature field displaying proportional Darcy velocity vectors (after MÁDL-SZÖNYI \& Tóth A. 2017). See Figure 1. for the trace of the section $A 1-B 1$ 
akkor nem éri el a Gödöllői-dombságot (8. ábra, $c, d$ ). A szelvény Dunától nyugatra fekvő része a Zsámbéki-medencét leszámítva fedetlennek tekinthetô. A keleti egységben a karbonátos víztartók fedett helyzetben vannak, 1500 m vastag paleogén és neogén, uralkodóan sziliciklasztos összlet alatt.

A nyugati régióban az áramlási kép alapvetôen igen hasonló az egységmedence (ТóTH J. 1962, 1963) mintázatához. Eltéréseket mindössze a felső 500-1500 m vastag medencerészben tapasztaltunk (8. ábra, $b$ ). A szelvény nyugati részén, a Zsámbéki-medencén belül rétegeken keresztüli leáramlás figyelhető meg. A 10-22 km közötti szelvényszakaszon a vezető vetők elősegítik az utánpótlódó vizek mélybe jutását. A Duna felé irányuló vízáramlás a Zsámbéki-medence keleti peremétől indul és utánpótlódása Budaörs, a Széchenyi- és Orbán-hegy területén is kimutatható $(8$. ábra $b, c)$. Ez az áramlás két rendszerre bontható. A felszínhez közelebbi rendszer feláramlása a Dunától nyugatra történik és szerkezetileg segített (8. ábra, $b, 27 \mathrm{~km})$. A rendszer mélyebb felszín alatti vízáramlása a Duna alatt folytatódik, így a víz egy része tovább halad kelet felé, másik része azonban a Dunánál megcsapolódik. A medence keleti, fedett része alatt a vízáramlás a fedőben zajlik, uralkodóan vízszintesen a Duna irányában, függőlegesen lefelé irányuló komponenssel (8. ábra, $c$ ) jellemezhető.

A területen zajló vízáramlás intenzitásában megmutatkozó különbségeket a Darcy-vektorok jelzik (8. ábra, $d$ ). A 15-30 km közötti szelvényszakaszon intenzív vízáramlás zajlik, ezzel szemben a vízforgalmi kapcsolatok mennyiségi értelemben mind a nyugati, mind pedig keleti irányban elhanyagolhatóak. Ugyanakkor a vízáramlási kép egésze szempontjából az ezen a szakaszon kívül esố részeknek (8. $a ́ b r a, c)$ is fontos szerepe van, rámutatnak ugyanis a vízáramlás aszimmetrikus jellegére (8. ábra, $c, d$ ). A jelenség oka valószínúleg a fedett és a fedetlen medencerészek közötti hidraulikus vezetőképesség, és beszivárgás mennyiségi különbsége. Az aszimmetrikus áramlási kép egyértelmúen jelzi, hogy bár mennyiségileg elhanyagolható mértékben, de a pesti oldal karsztos fedőképződményein át is érkezik víz az alatta található fedett karbonátba, mely hozzájárul a Dunánál történő megcsapolódáshoz (8. ábra, $c, d$ ).

A hőtranszport-modellezés eredményeként kapott hőmérséklet-eloszlás tükrözi a hő, felszín alatt áramló víz által közvetített advektív transzportját. Ezzel összefüggésben a fedett karbonátos területek alatt hőakkumuláció figyelhető meg a szelvény 0-5 km és 32-40 km-e között (vö. 8. ábra, $a$, d). A K-i terület alatt a hőszállítás advektív módon történik a megcsapolódási terület forrásai felé $(8 . a ́ b r a, d)$. A fedett karbonátos víztartó felsô részében a hômérséklet $>70{ }^{\circ} \mathrm{C}$ a pesti oldalon, míg 20-30 ${ }^{\circ} \mathrm{C}$ a Dunánál (MÁDL-SzŐNYI \& TóTH Á. 2017).

\section{A vízáramlási rendszerek és a hôtranszport változásai a miocén végétól máig}

A vízáramlás- és hőtranszport-modellezést a BTK miocéntől értelmezhetô három földtani fejlődéstörténeti fázisára (GYŐRI et al. 2011, PoROS et al. 2012, módosítva in
MindSZENTY szerk. 2013) is elvégeztük a Heatflow-Smoker véges elemes szoftver (MoLSON \& FRIND 2015) segítségével (HAVRIL et al. 2016). A vizsgálat során a rendszer valós paramétereiből indultunk ki, ugyanakkor a folyamatok követhetősége érdekében a modellezés során egyszerúsítésekkel éltünk. A tanulmány regionális léptéke és céljai miatt — az előzőekhez hasonlóan - EPM megközelítést alkalmaztunk, ugyanakkor e szimuláció során a felhajtóerő hatásával is számoltunk. A modellek határfeltételei, a képződmények fizikai tulajdonságai HAVRIL et al. (2016) munkájában megtalálhatók.

A numerikus szimuláció során a késő-miocénre jellemző teljesen fedett karbonátos rendszerből indultunk ki, amely a szárazulattá válás előtti időpillanatot képviseli (9. ábra, a). A következő, a késő-pliocén viszonyoknak megfelelő állapotot a 9. b ábra szemlélteti, mely a Budai-hegység kiemelkedése és eróziója által előidézett hatásokat, valamint a Gödöllői-dombság kiemelkedésének megindulását mutatja. A harmadik fázis a nyugati blokk kvázi fedetlenné válása révén bekövetkező változásokat szemlélteti a mai, fedett és fedetlen karbonát határán elhelyezkedő rendszerben (9. ábra, c). A tranziens modellezés segítségével követhetővé vált a felszín alatti vízáramlást előidéző főbb hajtóerôk és a hőmérséklet-elosztást befolyásoló folyamatok jellege, valamint az egyes hajtóerők relatív jelentősége.

A teljesen fedett állapotot reprezentáló elsô fázisban a kis hidraulikus vezetôképességú fedőréteg megakadályozza az alulról érkező hő rendszerből történő elszökését, mely a rendszer felfútését idézi elő. A fluidum mozgását és a hőmérsékleti viszonyokat a rendszer alsó és felső határa közötti hőmérséklet-különbség határozza meg. A kifejlődő komplex, konvekciós cellák által uralt vízáramlási rendszer a termikus felhajtóerô domináns hatására utal (8. ábra, a). A következő, átmeneti fázisban a nyugati blokk csökkent fedővastagsága révén a csapadékeredetû víz rendszerbe történő beszivárgásának megindulása módosítja a felszín alatti vízáramlás jellegét, hatást gyakorol a hajtóerőkre, valamint előidézi a rendszer húlését. A nyugati blokk kiemelt helyzete miatt a rendszer ezen részében szerepet kap a domborzati hajtóerô, mely alárendelten a kevésbé kiemelt K-i blokk fedőképződményében zajló vízáramlásban is szerepet játszik. E fejlődéstörténeti szakaszban azonban a vízáramlást és hőeloszlást továbbra is a hőkonvekció uralja (9. ábra, b). A jelenlegi állapotot képviselő harmadik fázisban a „,fedetlenné" vált nyugati blokkon keresztüli intenzív beszivárgás jelentős változásokat idézett elő a rendszerben (9. ábra, c). A hajtóerôket tekintve ekkorra már egyértelmúen a domborzat vízáramlást generáló szerepe érvényesül a hőkonvekció kisebb részaránya mellett. Megfigyelhető továbbá, hogy a keleti blokkban a fedőképződmény szigetelő hatása miatt kedvezô viszonyok uralkodnak a konvekciós cellák múködéséhez, különösen a K-i peremhez közeli területeken. Így a fedő szigetelő hatása jelentôs hőfelhalmozódást idéz elő a rendszer ezen részében (HAVRIL et al. 2016). A nyugati terület mélyebb zónáiban ugyancsak számolhatunk konvekciós cellák jelenlétével, melyet a Rayleigh-szám kritikusnál nagyobb értéke is jelez. 
a 1. fázis: Korai késö-miocén fedett karbonátos rendszer (kb. 11 millió év) Stage 1: Early Late Miocene confined carbonate system (approx. $11 \mathrm{Ma}$ )
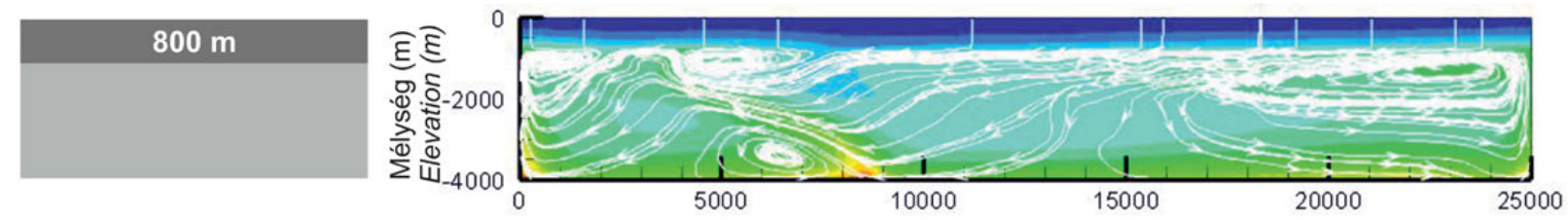

(b) 2. fázis: Késő-pliocén kiemelkedés a határok mentén (kb. 3 millió év) Stage 2: Late Pliocene uplift along the boundaries (approx. $3 \mathrm{Ma}$ )
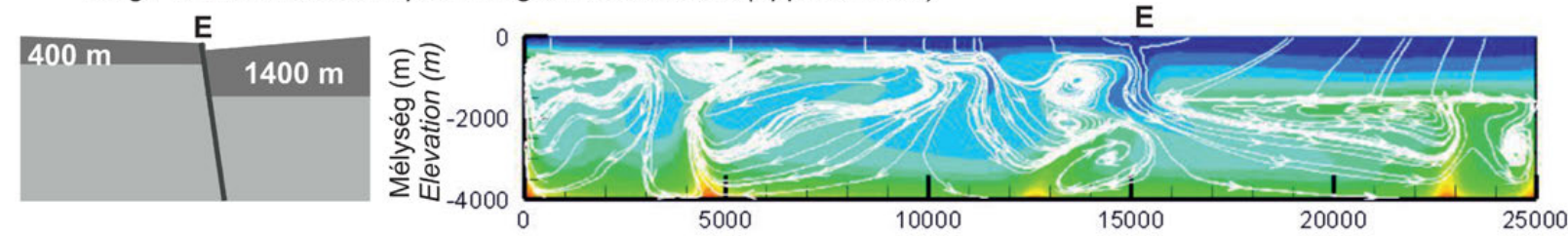

3. fázis: Mai állapotra jellemző fedetlen karbonátos nyugati blokk és fedett karbonátos keleti blokk Stage 3: Recent uncovered western part and confined eastern part
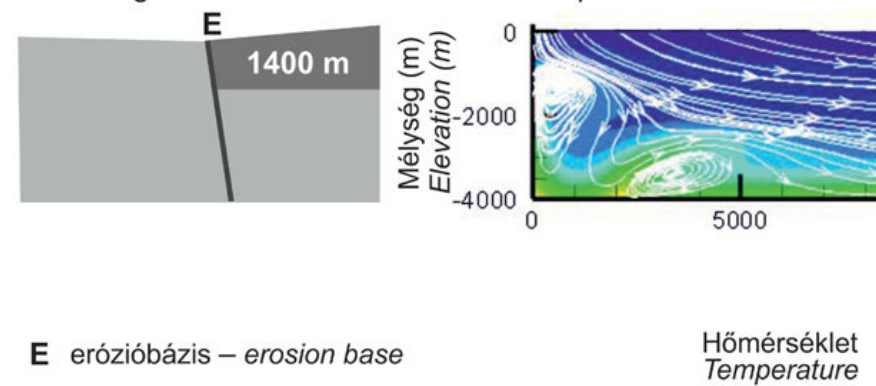

E erózióbázis - erosion base

Temperature

$101520253035404550556065707580^{\circ} \mathrm{C}$

9. ábra. A Budai-termálkarszt főbb geológiai fejlődéstörténeti fázisainak felszín alatti vízáramlási képe és hőmérséklet-eloszlása a) a korai késő-miocénre jellemző fedett karbonátos rendszertől b) a késő-pliocén kiemelkedésén át c) a részben fedetlenné váló mai rendszerig (módosítva HavRIL et al. (2016) után)

Figure 9. Groundwater flow and heat distribution of the main geological evolutionary stages from the early Late Miocene confined carbonate system a) through the Late Pliocene uplift b) to the recent partly uncovered system c) (HAVRIL et al. 2016). See Figure 1. for the track of the section A2-B2

\section{Diszkusszió és következtetések}

\section{Fluidumáramlási rendszerek és kapcsolódó folyamataik a miocéntól napjainkig}

A BTK fluidumfejlődését tekintve hosszú időn keresztül a pliocén-pleisztocéntől napjainkig tartó állapotra levezetett ún. kétfázisú, vagyis „zárt cellás” (fedett) és „,nyílt cellás”, (nyílt tükrú) modell volt érvényben (KovÁcS \& MüLLER 1980, LEÉl-ÔSSY 1995, NÁDOR 1991, TAKÁCS-BOLNER 1989). A hőmérsékleti hatótényezôt vulkáni tevékenységre vezették vissza (BALLA \& KoRPÁs 1980, JAKUCS 1950, SCHRÉTER 1912). Poros (2011), Poros et al. (2012) valamint GYŐRI et al. (2011) azonban rámutattak, hogy a hidrotermás fluidumok miocéntől való megjelenéséért a Pannon-medence miocén extenziója révén megemelkedő hőfluxus (ROYDEN \& HorvÁTH 1988) tehetô felelőssé. GYÓRI et al. (2011) és Poros et al. (2012, módosítva in MindSZENTY 2013) a korábbiaktól eltérôen már három fejlődéstörténeti fázist különít el a miocéntől: (1) fedett karbonátos állapot, tenziós barit-kalcit-telérekkel, szulfidásványokkal; (2) a pliocén kiemelkedés az erózióval, a barlangképződés kezdete; (3) pleisztocén és holocén barlangképződés, szpeleotémák kialakulása és édesvízimészkő-képződés.
Az elsô fázis (1) a rendszer teljesen fedett állapotát képviseli, amely során a tengeri eredetú vízzel kitöltött rendszer pórusterében történô vízáramlást a termikus felhajtóerő idézte elő (9. ábra, a). Poros (2011) a barit I - kalcit - barit II telérek és kapcsolódó paragenezisek regionális elterjedését jelzi a területen, melyet a központi (barit II) és déli rendszerből (barit II) származó baritásványok kénizotópösszetételének hasonlósága is megerősít (I. táblázat, 2. ábra). Mindezek a BTK területén egységes áramlási rendszerre utalnak. A teljesen fedett (felülről zárt) rendszerben a meghatározó karsztosodási folyamat a modellezéssel kimutatott konvekciós cellák feláramló ágának húlése által megújult oldóképesség lehetett (ANDRE \& RAJARAm 2005). A konvekciós cellákban időszakosan felfelé mozgó - és fokozatosan húlő -, majd lefelé mozgó — és emiatt felmelegedő — víz a kalcit $\delta^{18} \mathrm{O}$ értékeinek szórására is magyarázattal szolgálhat (GYóRI et al. 2011, PoROs et al. 2012). A paragenezisben megtalálható ásványok jelentős kéntartalommal bírnak. A kéntartalmú ásványok közül a barit II az utolsó repedéskitöltő fázis, mely a környezet oxidatívabbá válását jelzi (Poros et al. 2012), egyúttal átvezet a következő fejlődéstörténeti szakaszba, mely során a budai oldal kiemelkedése és a csapadék beszivárgása oxigént juttatott a korábban teljesen reduktív állapotú rendszerbe (9. ábra, b). 
A pliocéntől (2) a Budai-hegység szelektív kiemelkedésével (KELE 2009; KELE et al. 2011; RUSZKICZAY-RÜDIGER et al. 2005a, b, c; SZANYI et al. 2012; WEIN 1977) a domborzati hajtóerố is szerepet kapott, megindítva a hévforrás-tevékenységet és a vele járó barlangképződés napjainkban is — változó intenzitással — zajló folyamatát. A beszivárgó csapadékvíz a módosult tengervizet fokozatosan kiszorította a pórustérből. A forrástevékenység megindulásával megkezdődött az édesvízi mészkő kiválása (SCHEUER \& SCHWEITZER 1980, KELE 2009). A travertínó oldási maradékában felismert fluorit és barit (KovÁCS-PÁlFFY \& FöldVÁRI 2004, KELE 2009) arról tanúskodik, hogy a forrásukat tápláló fluidumáramlási rendszer a fedett szakaszban múködő áramlási rendszerből fejlődött tovább (Poros 2011). Az oldási maradékban megjelenő gipsz azonban már változást tükröz (KovÁcs-PÁLFFY \& FöLDVÁRI 2004). A miocénben domináns barit szerepét fokozatosan a gipsz vette át a rendszer fejlődésének előre haladásával (PoROS 2011).

A fluidumok szempontjából új elem a Pesti-síkság és a Gödöllői-dombság felől a rendszerbe érkező vizek bevonása a fejlődéstörténetbe (7. és 8. ábra). Ugyanakkor a medence fluidumnak az Alföld aljzatában kimutatott túlnyomás révén történő hozzájárulását — ahogyan azt korábban ALMÁsi (2001) nyomán Poros et al. (2012) feltételezte —, az adatfeldolgozás és a numerikus modellezés nem igazolta (HAVRIL et al. 2016). A medence fluidum hozzájárulás valószínúsíthetôen a Gödöllői-dombság 4 millió éve megkezdődött kiemelkedéséhez köthető (RUSZKICZAY-RÜDIGER et al. 2007), melynek hatására a rendszer keleti területein is domborzati hajtóerő alakult ki (9. ábra, b). A Gödöllőidombságon kezdődő beszivárgás és a kialakuló domborzati gradiens megindította a pórustérben tárolt ,,medence fluidumok" keletről nyugatra áramlását, valamint lefelé, egészen a karbonátos alaphegységi képződményekig történő szivárgását (7. ábra, c). A kiemelkedés egyidejûleg hozzájárulhatott a BTK K-DK-i irányú elkülönüléséhez (6. ábra).

A pliocéntől a medence fluidumok jelenléte miatt az agresszív gázok - mint a kén-hidrogén — oldó hatása is szerepet kaphatott a karsztosodásban. A kén-hidrogén gázt tartalmazó víz eltérô összetételú vízzel keveredve még hatékonyabb oldódást tesz lehetővé a keveredési korrózió és a kén-hidrogén oldóképességének megújulása révén (PALMER 2007). A feláramló és húlő víz karbonátok szempontjából korrozív hatásával a felhajtóerô által vezérelt áramlások környezetében továbbra is számolhatunk. Továbbá a különbözô eredetú fluidumok együttes jelenléte miatt a medencefluidumok és a karsztvíz közötti keveredési zónában is feltételezhető karsztosodás (GRAY \& ENGEL 2013, MÁDLSZŐNYI \& TÓTH Á. 2015).

A pleisztocén végétől máig tartó fejlődéstörténeti fázisban (3) a Budai-hegység és a Gödöllői-dombság kiemelkedésével párhuzamosan, a domborzati hajtóerő pleisztocén végétől máig tartó növekedésével kell számolnunk, a felhajtóerő szerepének csökkenése mellett (9. ábra, c). Ezt a helyzetet tovább árnyalják a pleisztocén során, klimatikus hatásra, a rendszerben tárolt víz mennyiségében bekövetkezô változások, melyek az ásványkiválásokban és a traver- tínó képződésben egyaránt nyomozhatók (KELE 2009, MinDSZENTY szerk. 2013).

\section{Jelenlegi regionális léptékú vízáramlási rendszerek}

A kutatás a mért adatokkal vizsgálható mélységig igazolta a domborzati magasságkülönbségek által vezérelt vízáramlási rendszerek jelenlétét (ERHARDT et al. 2017, MÁDLSzÓNYI et al. 2015, 2017, ÖTvÖs et al. 2017) (8. ábra). A BTK-ra vonatkozó korai koncepcionális modellek által leírt (KovÁcs \& Müller 1980, Vendel \& Kisházi 1964), Duna alatti átáramlást és az áramlás termálforrásokhoz történő részleges visszajutását a vízáramlási kép modellezése kvantitatívan alátámasztotta. A hidraulikai adatfeldolgozás megerősítette a Duna felszínalattivíz-megcsapoló szerepét, a térfelszín és a $-50 \mathrm{mBf}$ közötti tartományban, mely egy Ny-K-i irányú átáramlási zóna fölött jelenik meg (ERHARDT et al. 2017) (5. ábra). A központi rendszerre vonatkozóan vízgeokémiai modellezéssel meteorikus és hidrotermális eredetú keveredési komponenseket tudtunk levezetni, míg a déli rendszer természetes megcsapolásánál csak hidrotermális komponens mutatható ki (ERőss et al. 2012a, b).

Az archív forrásadatokra vonatkozó hierarchikus klaszteranalízis eredményei — a modellezés és az adatfeldolgozás eredményeivel összhangban — rámutattak arra, hogy a helyi, köztes és regionális áramláshoz köthető források paraméterei szisztematikusan összefüggnek a fakadási szint magasságával, utalva a domborzati hajtóerô szerepére. A legnagyobb vízhozammal a köztes áramlásokhoz köthető langyos források rendelkeznek. A legalacsonyabb fakadási szinttel a regionális, termálforrások jellemezhetôk (4. ábra). Kizárólag a regionális források mutatnak a karsztvizek összetételéhez képest nagyobb kloridtartalmat, mely a medence fluidumok hozzászivárgásából adódik. ALFöLDI (1979) felismerését, miszerint a karbonátos alaphegységi tároló fedett, keleti részén található miocén és oligocén medenceüledékek hidraulikailag kapcsolatban lehetnek a karbonátos alaphegységi rezervoárral, modellezéssel és az összes oldottanyag-tartalomra vonatkozó adatok feldolgozásával is sikerült igazolni. ALFÖLDI et al. (1968) és ALFÖLDI (1981) koncepciós modelljével megegyezően, numerikus szimulációval és a források adatai alapján a budai, nyugati területen belül két áramlási ágat (köztes és regionális) lehet elkülöníteni, ugyanakkor azok hidrosztratigráfiai egységek mentén történő elkülönülése nem igazolódott.

A kutatás választ adott a rendszer keleti határának korábbiakban nem kezelt kérdésére (6. ábra), valamint a karbonátokat fedő sziliciklasztos üledékekben tárolt medence fluidum - függôleges átszivárgással történô karsztba jutásának mechanizmusára (7. ábra) (MÁdLSzŐNYI \& TóTH Á. 2015, MÁdL-SzŐNYI et al. 2015). Így ERóss et al. (2011a) és Poros (2010) a medence fluidumok túlnyomásos eredetére vonatkozó korábbi meglátását, az eredmények tükrében nem látjuk bizonyíthatónak. A sziliciklasztos medencéból a karbonátos víztartóba az uralkodóan NaCl-os medence fluidummal együtt metán és kén- 
hidrogén is szállítódik (ERŐss et al. 2012a, MÁDL-SzŐNYI \& TóTH Á. 2015), ahogyan erre a Paleogén-medence kutatása során rámutattunk (MÁDLNÉ SZŐNYI et al. 2013).

A vizsgálatok megerősítették, hogy a Dunától Ny-ra eső területek domináns anionja a szulfát, mely a meteorikus és a hidrotermális szélsôtagokban is megtalálható, jelezve annak eltéró eredetét. Korábbi szerző́k a budapesti termálvizek szulfáttartalmát részben a Tardi Agyag formáció piritjének oxidációjából származtatták (in SzABó et al. 2009). VETŐ et al. (1999) közöl adatot az Alcsútdoboz-3 fúrásból, melyben a Tardi Agyag piritjéből származtatható összes $\delta^{34} S$-tartalmát átlagosan 2,6\%o-nek adja meg. Ez a hipotézis elfogadható a helyi és a köztes vízáramlási komponensre, ugyanakkor vizsgálatainkból mindössze egy, a Budai Márga Formációból származó adat áll rendelkezésre (I. és III. táblázat, 2. és 3. $a ́ b r a)$, így ezen feltételezés bizonyításához további mérések szükségesek.

A budapesti termálvizek szulfáttartalmát SzABó et al. (2009) stabil kénizotópos vizsgálatok alapján perm korú evaporitok beoldódásából származtatja. A szulfáteloszlásban tapasztalt anomáliákat összevetve a felsô-perm karbonát- és evaporitképződmények elterjedésével és előfordulásuk tengerszint feletti magasságával $(-500--1500) \mathrm{mBf}$, HAAS et al. 2010 térképe alapján), egyezést találunk (2. és 3. ábra). Üledékes szulfátokon HÁmOR (1991) által mért $\delta^{34} \mathrm{~S}$ adatok a perm korú minták átlagára $12,78 \%$, míg a triász korú minták átlagára 24,28\%o-et adtak. Ugyanakkor a termálkutakból származó minták (III. táblázat és 3. ábra) a központi és északi rendszerre szignifikánsan eltérô szulfáttartalmat jeleznek és 7,4-17,7\% o közötti kénizotóp értékeket mutattak, mely adatok az eredetre vonatkozó korábbi hipotézis további árnyalását teszik szükségessé. Felmerülhet a $\mathrm{H}_{2} \mathrm{~S}$ mint kénforrás szerepe is, mely a medence eredetú fluidum komponenssel együtt szállítódhat. Ezt saját adataink (MÁdLNÉ SzŐNYI et al. 2013) mellett, MACHEL (1992) tanulmánya is megerősíti. Irodalmi adatok alapján a $\mathrm{H}_{2} \mathrm{~S}$ kénizotóp értéke $\delta^{34} \mathrm{~S}=10 \%$ (ERôss et al. 2011b), mely magyarázhatja a tisztán evaporit értékek alapján vártnál kisebb mért értékeket.

Az ALFöLDI et al. (1968) és ALFÖLDI (1981) által feltételezett geotermikus ,vezérlés” máig tartó részleges megőrződését a karsztrendszer mély és főleg fedett régióiban HAVRIL et al. (2016) áramlási és hőtranszport modellezése megerósítette. PoyAnMeHr (2016a, b) három dimenziós numerikus modellezésével az eltérô célok miatt, e kutatás eredményei nem vethető́k össze.

A feldolgozás alapján vázolt koncepciós modell (10. ábra) leírja a BTK fedett és fedetlen karbonátos területén várható áramlási viszonyokat, valamint azok vízminőségre, források rendúségére (hideg, langyos, termál), valamint kloridtartalmára, vízhozamára és hőmérsékletére gyakorolt hatásait. A fedett térrész alatt számottevő hőfelhalmozódás és egy hidraulikailag determinált határfelület alakul ki. Az aljzat felől a források felé irányuló hőcsóva e határfelület mentén jelzi a hőszállítást. A karsztvíz és a fedőből érkező medence fluidumok áramlási határán jelenleg is számíthatunk hipogén karsztosodásra, melyben a keveredési korrózió játszhat meghatározó szerepet. Az advekció és a konvekció révén feláramló és fokozatosan húlő víz oldóképessége zárt rendszerben nő, mely további hipogén karsztosodási folyamatokat gerjeszthet a fedett rendszerben (ANDRE \& RAJARAM 2005, BAKALOWICZ et al. 1987, DUBLYANSKY 2000).

\section{A központi és déli rendszer vizeinek áramlási rendszerekból következó elkülönülése}

A BTK egységes áramlási rendszerén belül a tanulmányban vizsgált központi és déli rendszerekben feláramló vizek, valamint az azokat tápláló áramlási rendszereik jellegében különbségek mutatkoznak, melyre korábbi szerzôk is rámutattak (ALFÖLDI et al. 1968, ERŐss et al. 2008, PAPP 1942).

A központi és a déli rendszer elkülönülésében hidraulikai szerepet játszhat az ÉK-i peremvetố torlasztó hatása (5. ábra). ERHARDT et al. (2017) és ÖTVÖs et al. (2017) úgy véli, hogy a peremvetố szerepet játszhat abban, hogy a Rózsadomb elóterében két áramlási összetevő, míg a Gellért-hegy elôterében csak hidrotermális vizek jellemzőek. A Gellért-hegytôl Ny-ra ugyanis egy köztes áramlási ág végződik, mely ERHARDT \& ÖTvÖs (2011) alapján a Kis-Gellért-hegy vizeivel azonos (8. ábra).

Ugyanakkor felmerül, hogy hogyan lehetséges a Duna alatti átáramlás egy torlasztó vetőn keresztül. FoDOR et al. (1994) tanulmánya alapján a területen vezetô vetôket feltételezve azok torlasztó hatásával akkor kell számolnunk, ha a vetô két oldalán eltérô vízvezetô képességú képződmények érintkeznek. A vízmozgás iránya a vezető vetőben a környezô potenciáleloszlás függgvénye, ennek megfelelően fel- és leáramlás, valamint átáramlás is lehetséges rajta keresztül. Így az ÉK-i peremvetőn, mint vezető vetôn keresztül kimutatott Ny-K-i irányú horizontális áramlás a budai oldalon nagyobb, míg a pesti oldal kisebb folyadékpotenciál értékének a következménye. Elsố közelítésben ott lehetséges az átszivárgás a vetôn, ahol a vetô mindkét oldalán jó vízvezetô-képességú kôzetek találhatók (5. ábra, b és 8. ábra).

A kutatás rámutatott arra, hogy a központi rendszer vizeiben — a déli rendszerhez képest — a medencekomponens aránya a hidrotermális szélső tagban nagyobb (AlFöLDI et al. 1968, ERŐss et al. 2012b, POROS et al. 2012) (II. táblázat). A déli rendszerben ugyanakkor a szulfát és magnézium szerepe hangsúlyosabb. Ezt a különbséget tovább árnyalja a $\mathrm{H}_{2} \mathrm{SiO}_{3}$ mellett a $\mathrm{CO}_{2}, \mathrm{H}_{2} \mathrm{~S}$ és $\mathrm{CH}_{4}$ eltéró mértékú jelenléte. A magasabb kovasavtartalom összhangban van a magasabb hőmérséklettel, és utalhat az áramlások északi rendszerben jellemzően nagyobb behatolási mélységére, mint a déli rendszerben. A két rendszer a miocén korú, metántartalmú szénhidrogénzárványok tekintetében is elkülönül. Ezek ugyanis csak a központi rendszerből származó mintákban voltak kimutathatók, a déliekből nem (Poros 2011). Hasonlóképpen a jelenlegi vízmintákon elvégzett elemzések alapján szénhidrogén-indikáció csak a központi rendszer termálkútjaiban volt kimutatható, a déliben nem (ERôss 2010) (II. táblázat). 


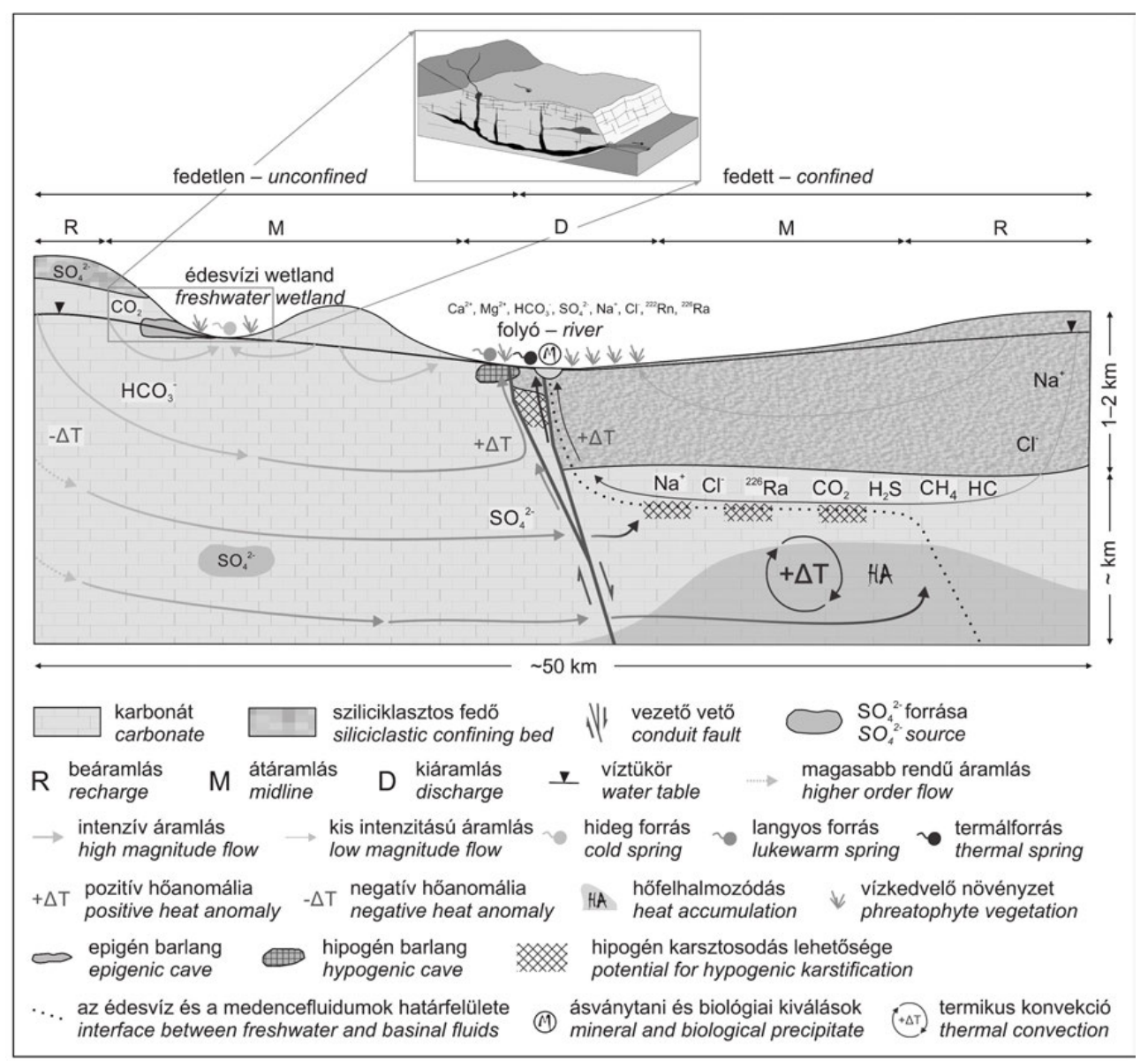

10. ábra. Általánosított modell a vízáramlások, hőszállítás és a kapcsolódó jelenségek bemutatására a BTK fedett és fedetlen karbonátos határterületére. A sekély karsztos vízadó (módosítva GOLDSCHEIDER \& DREW 2007 után) a regionális áramlási kép helyi rendszereként értelmezhető (módosítva MÁDL-SzŐNYI \& TóTH Á. 2015 után)

Figure 10. Conceptual groundwater flow model and its consequences of flow-related manifestations for the interface of confined and unconfined carbonates on the basis of the Buda Thermal Karst. The shallow karst aquifer (modified after GOLDSCHEIDER \& DREW 2007) is embedded into the regional flow pattern as a local system (modified after MÁDL-SZÖNYI \& TóTH Á. 2015)

A központi rendszer esetében az köztes és regionális megcsapolódás egymás közelében, mégis hidraulikailag elkülönülten történik. A kutak kémiai összetétele a levezetett meteorikus és hidrotermás vizek lineáris keveredési arányát mutatják (ERôss et al. 2012b). A BTK vizeinek klaszteranalízise (1960-2009) a központi rendszerre vonatkozóan elkülönítette a meleg vizek és a mélykarsztvizek csoportját (DÉRI-TAKÁCS et al. 2015), melyet (KovÁCS \& ERőss 2017) CCDA módszer segítségével további alcsoportokra bontott, elkülönítve a Lukács kutakat, a Margitsziget kútjait és a pesti oldal kútjait, bizonyítva azok különbözőségét. Ezek a csoportok a központi terület regionális áramlási rendszerének hidrotermális fluidumkomponenseit reprezentálják (a medence-komponenssel együtt). A csoportok elkülönülésének további oka az lehet, hogy a kutak esetében a köztes áramlási komponens meteorikus eredetú vizeinek különböző arányú hozzákeveredésével is számolnunk kell. Ezt támasztják alá a központi rendszer termálkútjaiban mért kénizotópértékek, melyek lineáris összefüggést jeleznek. Egyúttal a termálkutak $\delta^{34} \mathrm{~S}$ értékeinek langyos forrásokhoz képest pozitív irányú eltérései különböző erdetre utalnak (III. táblázat és 3. ábra). Ez megerősíti a központi rendszerhez sorolt termálkutak és a langyos források eltérő víz és kén eredetét. Mivel a termálkutak vizeinek $\delta^{34} \mathrm{~S}$ alsó értékei közel állnak a kén-hidrogén izotópértékéhez (10\%o), így valószínúsíthetően a kén-hidrogénnek, mint kén-forrásnak is lehet szerepe (III. táblázat, 3. ábra).

A kémiai szélső tagok (II. táblázat) között kimutatott különbségek a langyos források kénizotóp-összetételében is tükröződnek (SzABó et al. 2009). Ezek ugyanis sokkal közelebb állnak a Molnár János-barlangban a Budai Márga Formációból származó pirit kénizotópértékéhez, mint a termálkutak izotópértékeihez (I. és III. táblázat, 2. és 3. ábra) (ERőss et al. 2011b, Poros et al. 2010). Azaz, a rózsadombi langyos források esetében a piritből származó eredet valószínúsíthetô. Ugyanakkor a Molnár János-barlang gipsz kiválása esetében számottevő hatást okozhat a redukált kénvegyületek bakteriális oxidációja, mely a kénizotóp-értékek negatív eltolódásában mutatkozik meg (I. táblázat, 2. ábra) (ANDA et al. 2017).

A déli rendszerre vonatkozóan csak hidrotermális szélsô tagot találtunk (ERőss et al. 2012b), ugyanakkor későbbi munkák a klaszteranalízissel egységesnek talált dél-buda- 
pesti vizeket (DÉRI-TAKÁCs et al. 2015), további két csoportra osztották a CCDA segítségével (KovÁCS \& ERôSS 2017). A szulfáteredet kérdésének vizsgálata itt is döntő lehet, a különbségek megértésében. Gondolnunk kell a már említett evaporitrétegekre a Dunától nyugatra, ugyanakkor nem csak alaphegységi perm és alsó-triász evaporitokkal számolhatunk. További lehetőségként adódik a déli rendszer miocén fedőképződményeiben, a Zsámbéki-medencében 260 m mélységben talált anhidritréteg (JÁMBOR 1974). A numerikus vízáramlás-szimuláció a Zsámbéki-medence fedőképződményein keresztül átszivárgást mutatott ki. Mivel a medence érintkezik azzal az intenzív vízáramlással jellemezhető zónával, mely Gellért-hegy, ill. a déli rendszer felé szállítja a vizeket, elképzelhetô a szulfát bekerülése a rendszerbe (8. ábra, $b, c)$.

A vizsgálati terület határának közelében — az 1. ábra határán kívül esô — Ráckeve-1 fúrásban 200 m vastag evaporit- (gipsz- és anhidrit-) réteg található (PALOTAI 2013). Jelenlegi vizsgálatainkkal ez nem hozható összefüggésbe, ugyanakkor a fúrás miocén korú tengeri anhidritjéből rendelkezésre álló $\delta^{34} \mathrm{~S}$ izotópadatok $(\sim 12-13 \%$ ) referenciaként szolgálhatnak (MÁDLNÉ SzŐNYI et al. 2013). Az, hogy a déli rendszer termálvizében a perm, alsó-triász, vagy a miocén evaporit játszik-e szerepet, az egyedi adatok és a közelálló értékek miatt nem dönthető el. A déli rendszer esetében a dél-pesti termálkutak kénizotópértékei (2. és 3. ábra) közel állnak mind a perm evaporitok átlagértékéhez, mind pedig a Ráckeve-1 fúrásból rendelkezésre álló adathoz. A kénizotópértékek a déli rendszer kútjaiban a Gellért-hegy előterében található kutak irányába csökkennek, míg a forrásokra a kutakhoz képest negatív irányú eltolódás figyelhető meg. Ez utóbbi a jelenlegi forrásmedencékben is megfigyelhető bakteriális aktivitással magyarázható (ANDA et al. 2015, ERőss 2010, ERőss et al. 2012a).

Az evaporit déli rendszerbe kerülésével egy újabb hipogén karsztosodási folyamat lehetôsége is felmerül. A gipsz, dolomit és kalcit közötti reakció során a gipsz oldódása elôsegíti a kalcit kiválását, amely a dolomit oldódásához és a víz kalcium- és magnézium-tartalmának növekedéséhez vezet (BIschoff et al. 1994, PALMER 2007, Plummer \& BACK 1980). Ez regionális skálán tekintve megnöveli a termálvíz magnézium- és a szulfáttartalmát. Elképzelhetô, hogy ez a folyamat felelős a szulfát és a magnézium déli rendszer termálvizeiben megfigyelt magasabb értékeiért (ERŐss 2010, ERŐss et al. 2012b).

\section{Összefoglalás}

A BTK késő-miocéntől tartó fluidum-fejlődéstörténetét egy új elemmel, a Gödöllői-dombság négymillió éve kezdődött kiemelkedésével egészítettük ki. Ezzel a BTK vízáramlási rendszereinek értelmezésébe bevontuk a fedett Pesti-síkságtól a Gödöllői-dombság vízválasztójáig tartó területeket. A dombság kiemelkedésének feltételezhetôen szerepe volt a BTK vízáramlási rendszereinek K-DK-i irányú elkülönülésében. E fedett régió — a domborzati hajtóerő kialakulásától kezdve egészen máig — hozzájárul a paleogén-neogén fedőüledékekből származó medence fluidumok termálforrásokhoz történő szállításához. Felvázoltuk az egyes szakaszokra jellemzô fluidumkomponenseket, numerikus vízáramlás-szimulációval kimutattuk a felhajtóeró és a domborzati hajtóerôk miocéntől változó jelentőségét a rendszeren beluil és ezzel párhuzamba állítottuk az egyes szakaszokra jellemző ásványfázisokat.

A jelenlegi állapotban a BTK-t egy részben fedetlen Nyi és egy fedett K-i félmedence egymással szoros kölcsönhatásban lévő aszimmetrikus áramlási rendszerével jellemezhetjük. Az aszimmetrikus jelleg a hidrosztratigráfiai helyzet (fedett-fedetlen területek érintkezése) és a K-i és Ny-i medencerészek közötti beszivárgáskülönbség következménye. A BTK Ny-i egységében a terület forráscsoportjai elkülönülnek fakadási szintjük, kloridtartalmuk, hozamuk és hőmérsékletük alapján. A hierarchikus klaszteranalízissel levezetett forráscsoportok illeszkednek a numerikus 2D stacioner szimulációval kimutatható helyi, köztes és regionális áramlásokhoz, jelezve azok természetes kiáramlási helyeit. A rendszer fô hajtóerejét ma már a vízszintkülönbségek adják, a felhajtóerő szerepe alárendeltté vált, s a fedett területek mélyebb régióiban maradt meg a jelentősége. A regionális vízáramlási rendszer Duna alatti Ny-ról K-re történő átáramlását és fölötte a Duna megcsapoló szerepét a hidraulikai adatfeldolgozás megerôsítette. Az áramlási rendszerekhez meteorikus és hidrotermális fluidumkomponenseket rendeltünk. A NaCl-os medencekomponens hozzájárulása a hidrotermális fluidumokhoz a K-i fedett félmedence domborzatilag vezérelt áramlásai révén, igazolást nyert. A Dunától Ny-ra esô területeken a nátrium-klorid jelenléte nem, viszont a szulfát és a magnézium magasabb koncentrációja kimutatható volt a vizekben. A szulfát részben a telítetlen zónában található pirit oxidációjából, részben pedig különböző korú (perm és alsó-triász, illetve miocén) evaporitokból származtatható a kénizotóp, hidraulikai adatok és numerikus szimuláció eredményeinek összevetése alapján. Az evaporit kétféle eredete nem zárható ki. A kutatás alapján vázolt általános modell az áramlási jelenségek bemutatása mellett a vízkémiai komponenseket és a kapcsolódó jelenségeket is bemutatja. A rendszer fedett része alatt jelentős hőfelhalmozódás tapasztalható és kimutattuk azt a hőcsóvát, mely a felhalmozott hő termálforrásokhoz juttatásáért felelős.

Mind a hidraulikai adatfeldolgozás, mind pedig a numerikus szimuláció bizonyítja a BTK hidraulikailag összefüggő áramlási rendszerét, melyben dominánsan hidrosztatikushoz közeli nyomásviszonyok uralkodnak, emiatt a beés kiáramlási területek kisebbek, a nagy kiterjedésú átáramlási zónákhoz képest. A szerkezeti elemek közül az ÉK-i peremvetô a Ny felől érkező vízáramlásokat felduzzasztja, aminek jelentősége lehet a Rózsadomb és a Gellért-hegy előterében fakadó források elkülönülésében. A vízáramlási modellezés eredménye arra is rávilágított, hogy a Gellérthegy mögött, a Kis-Gellért-hegy zónájában egy köztes áramlási rendszer jut a felszínközelbe. Ez lehet az oka, hogy a Gellért-hegy előterében csak egy termálvizes áramlás 
csapolódik meg. A Rózsadombon a langyos vizek megcsapolódása a termálvízforrások közelében, de azokhoz képest némileg magasabb tszf magasságon figyelhetô meg.

Az eredmények a rózsadombi és Gellért-hegy előterében felszínre jutó vízkomponensek hasonlósága mellett azok különbségére is felhívják a figyelmet, mely a két rendszer hidrotermális vizeiben mutatkozik meg. Ez a korábban radionuklidok alapján feltárt különbségeken túl, leginkább a szulfát- és kloridionok és a kapcsolódó kationok rendszerenként eltérô mennyiségében érvényesül, de megnyilvánul a nátrium-, magnézium- és a gáztartalomban is. A kutatás rávilágított arra, hogy a Gellért-hegy előtere esetében a medencekomponens hozzájárulás a hidrotermális komponenshez kisebb jelentőségú, viszont sokkal számottevőbb az a szulfáttöbblet, mely a DNy-on kimutatott evaporitrétegekkel is összefüggésbe hozható. Ezt a képet árnyalja a vizek kénizotóp-összetételében megnyilvánuló különbség a két rendszer között. A rózsadombi hidrotermális vizek esetében a kén-hidrogén, mint lehetséges szulfátforrás is felmerült. A meteorikus eredetú vizek esetében az izotópértékek és áramlási kép arra utal, hogy a szulfát a fedőüledékben található Budai Márga, Tardi Agyag pirittartalmából a fedôn keresztüli átszivárgással kerülhetett a megcsapolódó langyos vízbe.

Jelen tanulmányban vázolt eredmények a barlangképződési folyamatok értelmezéséhez is hozzájárulnak. A flui- dumkomponensek, a kimutatott áramlási kép és hőmérsékleti viszonyok alapján a hipogén karsztosodás több folyamatának egyidejú jelenlétét feltételezhetjük a rendszerben, a miocéntôl napjainking változó jelleggel.

\section{Köszönetyilvánítás}

A cikk szerzői elsődlegesen MiNDSZENTY Andrea professzor asszonynak szeretnének köszönetet mondani, aki az 1990-es évek második felében felismerte a tanulmány „megközelítésében” rejlő lehetőségeket, s ennek jegyében azonnal kutatásokat kezdeményezett, melyekben aktívan, témavezetőként részt vett. Köszönettel tartozunk az anyagvizsgálatokat végző, a terepmunkába és a numerikus szimulációba bekapcsolódó számos kollégának és hallgatónak. Ezúton fejezzük ki köszönetünket a Shell, Eni, Mol olajvállaltoknak, valamint az NKFI-nek az OTKA 101356 projekt támogatásáért. Végezetül, de nem utolsó sorban köszönjük a cikk névtelen lektorának és Almási Istvánnak, valamint SzTANó Orsolya főszerkesztőnek alapos és mélyreható észrevételeit, melyekkel hozzájárultak a kézirat véglegesítéséhez.

\section{Irodalom — References}

ALFöLDI L. 1979: Budapesti hévizek. — VITUKI kiadvány, Budapest, 102 p.

ALFÖLDI L. 1981: A budapesti geotermikus áramlási rendszer modellje. — Hidrológiai Közlöny 61/9, 397-403.

Alföldi L., Bélteky L., BöcKer T., Horváth J., Korim K., Liebe P. \& RéMI R. 1968: Budapest hévizei. — VITUKI, Budapest, 365 p.

AlFÖLDI, L. \& KAPOLYI, L. 2007: Bányászati karsztvízszintsüllyesztés a Dunántúli-középhegységben (Mining-dewatering in the Transdanubian Range). - Geography Institute of Hungarian Academy of Sciences, Budapest.

Almási, I. 2001: Petroleum Hydrogeology of the Great Hungarian Plain, Eastern Pannonian Basin, Hungary. — PhD dissertation, University of Alberta, $324 \mathrm{p}$.

Anda D., MAKk J., Krett G., MÁRIALIGETi K., Mádl-SzŐNYi J. \& Borsodi A. 2016: A Molnár János-barlang víz és biofilm baktériumközösségei. — Hidrológiai Közlöny 96/1,3-7.

Anda, D., Krett, G., MakK, J., Márialigeti, K., Mádl-SzŐNYi, J. \& Borsodi, A. K. 2017: Comparison of Bacterial and Archaeal communities from different habitats of the hypogenic Molnár János Cave of the Buda Thermal Karst System (Hungary). — Journal of Cave and Karst Studies 79/2, 113-121. http://doi.org/10.4311/2015mb0134

Anda, D., Makk, J., Krett, G., Jurecska, L., Márialigeti, K., Mádl-SzőnYi, J. \& Borsodi, A. K. 2015: Thermophilic prokaryotic communities inhabiting the biofilm and well water of a thermal karst system located in Budapest (Hungary). — Extremophiles 19/4, 787-797. https://doi.org/10.1007/s00792-015-0754-1

ANDRE, B. J. \& RAJARAm, H. 2005: Dissolution of limestone fractures by cooling waters: Early development of hypogene karst systems. — Water Resources Research 41/1, https://doi.org/10.1029/2004wr003331

Bakalowicz, M. J., Ford, D. C., Miller, T., Palmer, A. N. \& Palmer, M. V. 1987: Thermal genesis of dissolution caves in the Black Hills, South Dakota. — Geological Society of America Bulletin 99/6, 729-738. https://doi.org/10.1130/0016-7606(1987) 99\%3C729:tgodci\%3E2.0.co;2

BALla Z. \& KoRPÁs L. 1980: A Börzsöny hegység vulkáni szerkezete és fejlõdéstörténete (Volcanotectonics and evolution of the Börzsöny Mts). — MÁFI Évi Jelentés 1978, 78-101.

Bischoff, J. L., Juliá, R., Shanks, W. C. \& Rosenbauer, R. J. 1994: Karstification without carbonic acid: Bedrock dissolution by gypsum-driven dedolomitization. — Geology 22/11,995-998. https://doi.org/10.1130/0091-7613(1994)022<0995:kwcabd>2.3.co;2

Bodor, P., Tóth, Á., KovÁcs, J. \& MÁDL-SzÓNYI, J. 2015: Multidimensional data analysis of natural springs in a carbonate region. First EAGE/TNO Workshop: Basin Hydrodynamic Systems in Relations to their Contained Resources, Utrecht (6-8 May 2015). https://doi.org/10.3997/2214-4609.201412324

CSEPREGI A. 2007: A karsztvíztermelés hatása a Dunántúli-középhegység vízháztartására. — In: ALFÖLDI L. \& KAPOLYI L. (szerk.): Bányászati karsztvízszintsüllyesztés a Dunántúli-középhegységben. Magyar Tudományos Akadémia, Földrajztudományi Intézet, Budapest, 77-112. 
DEMING, D. 2002: Introduction to hydrogeology. - McGraw-Hill College, New York 480 p.

DÉRI-TAKÁCS, J., ERŐss, A. \& KovÁcs, J. 2015: The chemical characterization of the thermal waters in Budapest, Hungary by using multivariate exploratory techniques. — Environmental Earth Sciences 74/12, 7475-7486. https://doi.org/10.1007/s12665-014-3904-3

Dublyansky, Y. V. 2000: Hydrothermal speleogenesis: its settings and peculiar features. — In: KlimchouK, A., Ford, D., PALMER, A. \& DREYBRODT, W. (eds): Speleogenesis: Evolution of karst aquifers. National Speleological Society, 292-297.

ERHARDT I. \& ÖTVÖs V. 2011: Meteorikus fluidum hozzájárulás vizsgálata a Gellért-hegy környezetében megcsapolódó vizekben. — Tudományos Diákköri dolgozat, Eötvös Loránd Egyetem, 90 p.

Erhardt, I., Ötvös, V., Erőss, A., CZAuner, B., Simon, S. \& MÁdl-SzŐNYI, J. 2017: Hydraulic evaluation of the hypogenic karst area inBudapest (Hungary). — Journal of Hydrogeology 125/6, 1871-1891. https://doi.org/10.1007/s 10040-017-1591-3

ERŐss, A. 2010: Characterization of fluids and evaluation of their effects on karst development at the Rózsadomb and Gellért Hill, Buda Thermal Karst, Hungary. — PhD dissertation, Eötvös Loránd University, Budapest, 171 p.

Eróss, A., Csoma, É., Mádl-Szőnyi, J., Sasowsky, I., Feazel, C., Mylorie, J., Palmer, A. \& Palmer, M. 2008: The effects of mixed hydrothermal and meteoric fluids on karst reservoir development, Buda Thermal Karst, Hungary. — Karst from recent to reservoirs 14, 57-63.

ERŐss, A., MÁdlnÉ SzŐNYI, J. \& Csoma, A. É. 2011a: The effects of mixed hydrothermal and meteoric fluids on karst reservoir developmnet, Buda Thermal Karst, Hungary. — Shell-EMR Final Report, SR.11.11449.

Erőss, A., Poros, Z., MÁdl-SzŐnyi, J., Mindszenty, A., Molnár, F., Ronchi, P. \& Csoma, A. É. 2011 b: Role of karstic and basinal fluids in porosity evolution in the Buda Hills, Hungary. — AAPG International Conference and Exhibition 2011: Following Da Vinci's Footsteps to Future Energy Resources: Innovations from Outcrops to Assets AAPG, Paper 1071554.

ERŐss, A., MÁDL-SzŐNYI, J. \& CsOMA, A. É. 2012a: Hypogenic karst development in a hydrogeological context, Buda Thermal Karst, Budapest, Hungary. — Groundwater quality sustainability: IAH selected papers on hydrogeology 17, 119-133. https://doi.org/ $10.1201 / \mathrm{b} 12715-12$

ERŐss, A., MÁdl-SzŐNYI, J., Surbeck, H., HorvÁth, Á., GoldSCheIder, N. \& CsOMA, A. É. 2012b: Radionuclides as natural tracers for the characterization of fluids in regional discharge areas, Buda Thermal Karst, Hungary. — Journal of Hydrology 426, $124-137$. https://doi.org/10.1016/j.jhydrol.2012.01.031

FodOR L. 2013: A Budai-hegység K-Ny-i irányú földtani szelvénye. — In: MindsZENTY A. (szerk.): Földtani értékek és az ember. ELTE Eötvös Kiadó, Budapest, 311 p.

Fodor L., Magyari Á., Fogarasi A. \& Palotás K. 1994: Tercier szerkezetfejlődés és késő paleogén üledékképződés a Budaihegységben. A Budai-vonal új értelmezése (Tertiary tectonics and Late Paleogene sedimentation in the Buda Hills, Hungary. A new interpretation of the Buda line). — Földtani Közlöny 124/2, 130-305.

GÁl B., POROS Z. \& MOLNÁR F. 2008: A Hárshegyi Homokkő Formáció hidrotermális kifeljődései és azok kapcsolatai regionális földtani eseményekhez. — Földtani Közlöny 138/1, 49-60.

Goldscheider, N. \& DRew, D. 2007: Methods in Karst Hydrogeology. — International Association of Hydrogeologists, CRC Press. https://doi.org/10.4324/9780203934623

GRAY, C. J. \& ENGEL, A. S. 2013: Microbial diversity and impact on carbonate geochemistry across a changing geochemical gradient in a karst aquifer. — The ISME journal 7/2, 325-337. https://doi.org/10.1038/ismej.2012.105

Gyalog L., Maros G. \& Pelikán P. 2016: Budapest geokalauza. — Magyar Földtani és Geofizikai Intézet Budapest, 314 p.

GyôRi O., Poros Z., Mindszenty A., Molnár F., Fodor L. \& SZABÓ R. 2011: Budai-hegységi paleogén karbonátos kőzetek diagenezistörténete. - Földtani Közlöny 141/4, 341-361.

HaAs J., Budai T., Csontos L., Fodor L. \& KonRÁd G. 2010: Magyarázó Magyarország pre-kainozoos földtani térképéhez 1:500 000 (Explanation to the Pre-Cenozoic geological map of Hungary). — Magyar Földtani és Geofizikai Intézet, Budapest.

HÁMOR T. 1991: Az anoxikus üledékképződés és a korai diagenezis vizsgálata stabil izotóp mérések alkalmazásával. — Az Országos Tudományos Kutatási Alap 259. sz. téma zárójelentése, Magyar Állami Földtani Intézet.

Havril, T., Molson, J. W. \& MÁdL-SzŐNYI, J. 2016: Evolution of fluid flow and heat distribution over geological time scales at the margin of unconfined and confined carbonate sequences - A numerical investigation based on the Buda Thermal Karst analogue. — Marine and Petroleum Geology 78, 738-749. https://doi.org/10.1016/j.marpetgeo.2016.10.001

Ingebritsen, S. E., SANFord, W. E. \& NeuZIL , C. E. 2006: Groundwater in geologic processes. — Cambridge University Press, 564 p. IZÁPY G. 2002: Magyarország forrásainak katasztere. — VITUKI Rt. Hidrológiai Intézete.

JAKUCS L. 1950: A dolomitporlódás kérdése a Budai-hegységben — Földtani Közlöny 80/10-12,361-380.

JÁMBOR A. 1974: Üledékes kéntelep a Zsámbéki-medence szarmata sorozatában. — A Magyar Állami Földtani Intézet Évi Jelentése 1972-ról, 301-306.

KELE S. 2009: Édesvízi mészkövek vizsgálata a Kárpát-medencéből: paleoklimatológiai és szedimentológiai elemzések (Travertine studies from the Carpathian Basin: paleoclimatological and sedimentological analyses). — Doktori értekezés, Eötvös Loránd Tudományegyetem, Budapest, 262 p.

Kele S., Scheuer G., Demény A., ShEn, C.-C. \& ChiAng, H.-W. 2011: A Rózsadomb (Budapest) édesvízi mészköveinek U/Th sorozatos kormeghatározása és stabilizotóp-geokémiai vizsgálata (U/Th dating and stable isotope geochemical investigation of the travertines of the Rózsadomb (Budapest)). — Földtani Közlöny 141/2, 445-468.

KovÁCs-PÁlfFy P. \& FöldVÁRI, M. 2004: Északkelet-dunántúli édesvízi mészkövek ásványtana. — Földtani Közlöny 134, $563-587$.

KovÁCS J. \& ERÓSS, A. 2017: Statistically optimal grouping using combined cluster and discriminant analysis (CCDA) on a geochemical database of thermal karst waters in Budapest. — Applied Geochemistry 84, 76-86. https://doi.org/10.1016/j.apgeochem.2017.05.009

KovÁCS J. \& MÜLlER P. 1980: A budai-hegyek hévizes tevékenységének kialakulása és nyomai (Evolution and evidence of the thermal water activity in the Buda Hills). — Karszt és Barlang 1980/2, 93-98. 
LEÉL-Ốssy Sz. 1995: A Rózsadomb és környékének különleges barlangjai (Particular caves of the Rózsadomb Area). — Földtani Közlöny 125/3-4, 363-432.

LeÉl-Ôssy, S. 2017: Caves of the Buda Thermal Karst. — In: Klimchouk, A. N., PAlmer, A., DeWacle, J., Auler A. S. \& Audra, P. (eds): Hypogene Karst Regions and Caves of the World. Springer, 279-297. https://doi.org/10.1007/978-3-319-53348-3_18

Lenkey, L., Dövényi, P., Horváth, F. \& Cloetingh, S. 2002: Geothermics of the Pannonian Basin and its bearing on the neotectonics. - EGU Stephan Mueller Special Publication Series 3, 29-40. https://doi.org/10.5194/smsps-3-29-2002

MACHEL, H. 1992: Low-temperature and high-temperature origins of elemental sulfur in diagenetic environments. — Native SulfurDevelopments in Geology and Exploration, OneMine, Inc., 3-22.

Mádlné SzŐNYi J., CZAuner B., ERôss A. \& Simon S. 2013: Karbonátos és csatlakozó üledékes medenceterületek fluidumdinamikai összefüggéseinek vizsgálata a szénhidrogén kutatás hatékonyságának javítása érdekében a Paleogén-medencében. —Zárójelentés. Eötvös Loránd Tudományegyetem, Általános és Alkalmazott Földtani Tanszék, 200 p.

Mádl-Szőnyi, J., Czauner, B., Iván, V., Tóth, Á., Simon, S., Erőss, A., Bodor, P., Havril, T., Boncz, L. \& Sőreg, V. 2017: Confined carbonates — Regional scale hydraulic interaction or isolation? - Marine and Petroleum Geology, https://doi.org/10.1016/ j.marpetgeo.2017.06.006

MÁDL-SZŐNYI, J., PULAY, E., TÓTH, Á. \& BODOR, P. 2015: Regional underpressure: a factor of uncertainty in the geothermal exploration of deep carbonates, Gödöllő Region, Hungary. — Environmental Earth Sciences 74/12, 7523-7538. https://doi.org/10.1007/s12665-015-4608-Z

MÁdL-SzÓNYI, J. \& TóTH, Á. 2015: Basin-scale conceptual groundwater flow model for an unconfined and confined thick carbonate region. — Hydrogeology Journal 23/7, 1359-1380. https://doi.org/10.1007/s10040-015-1274-x

MádL-SzÓNYI, J. \& TótH, Á. 2017: Topographically driven fluid flow at the boundary of confined and unconfined sub-basins of carbonates: basic pattern and evaluation approach on the example of Buda Thermal Karst. — In: RENARD, P. \& BERTRAND, C. (eds): EuroKarst 2016, Neuchâtel: Advances in the Hydrogeology of Karst and Carbonate Reservoirs. Springer International Publishing, Cham, 89-98. https://doi.org/10.1007/978-3-319-45465-8_10

MARTinECZ Á. 2014: Hidrosztratigráfiai értékelés és áramkép szimuláció a Budai Termálkarszton. (Hydrostratigraphic distribution and groundwater flow simulation in the Buda Thermal Karst). — Szakdolgozat, Eötvös Loránd Tudományegyetem, Budapest.

MindSZENTY A. 2013: Budapest: Földtani értékek és az ember. — ELTE Eötvös Kiadó, Budapest, 312 p.

MindSZENTY A. \& MÁDL-SzŐNYI, J. 1999: A Rózsadombi termálkarszt monitoring múködtetése. — In: MindSZENTY A. \& MÁdL-SzŐNYI J. (szerk.), ELTE TTK Alkalmazott és Környezetföldtani Tanszék, 118 p.

Mindszenty A., Mádlné SzŐNyi J., ERőss A. \& Pethő S. 2001: A Budai Termálkarszt területén feltételezhető epikarszt vizsgálata. — ELTE TTK Alkalmazott és Környezetföldtani Tanszék, $50 \mathrm{p}$.

Mindszenty A., Mádl-SzŐnyi J., Pethô S., Kovács J., Müller I., Fodor L., KÁdár M., Angelus B., Erôss A., Nyúl K., Poyanmehr Z. \& VARGA R. 2000: Rózsadombi Termálkarszt Monitoring Optimalizálása. — Zárójelentés a 2000. évben végzett munkáról. ELTE TTK Alkalmazott és Környezetföldtani Tanszék, 111 p.

Molson, J. W. \& FrInD, E. O. 2015: HEATFLOW - SMOKER Version 7.0 - Density-dependent flow and advective-dispersive transport of thermal energy, mass or residence time in three-dimensional porous or discretely-fractured porous media. - Manuscript, Université Laval.

NÁDor A. 1991: A Budai-hegység paleokarsztjai. — Doktori értekezés, Eötvös Loránd Tudományegyetem, Általános és Történeti Földtani Tanszék, $171 \mathrm{p}$.

Ötvös V., Erhardt I., Erôss A., CZAuner B., Simon S. \& MÁdlnÉ SzŐNYi J. 2017: A Budai Termálkarszt hidraulikai viszonyainak barlangképződési vonatkozásai. — Karsztfejlődés 22, 5-33.

Palmer, A. N. 2007: Cave geology. - Cave books, 454 p.

Palotal, M. 2013: Oligocene-Miocene Tectonic Evolution of the central part of the Mid-Hungarian Shear Zone. — PhD dissertation, Eötvös Loránd University, Budapest, 235-248.

PAPP F. 1942: Budapest meleg gyógyforrásai. — Budapest Központi Gyógy-és Üdülőhelyi Bizottság Rheuma és Fürdőkutató Intézet.

Pentecost, A. 2005: Travertine. — Springer Science \& Business Media. https://doi.org/10.1007/1-4020-3606-X

Plummer, L. N. \& BACK, W. 1980: The mass balance approach: application to interpreting the chemical evolution of hydrologic systems. - American Journal of Science 280/2, 130-142. https://doi.org/10.2475/ajs.280.2.130

POROS, Z. 2010: Imprints of superimposed meteoric and thermal karst events on the porosity evolution of carbonate reservoirs - The case of the Buda Thermal Karst (Pannonian Basin, Hungary). — Final report, ENI S.P.A

Poros, Z. 2011: Fluid migration and porosity evolution in the Buda Hills, Hungary—selected examples from Triassic and Paleogene carbonate rocks. — PhD dissertation, Eötvös Loránd University, Budapest, 141 p.

Poros, Z., Erőss, A., MÁdl-SzŐNYI, J., Mindszenty, A., Molnár, F., Ronchi, P. \& Csoma, É. A. 2010: Mixing of karstic and basinal fluids affecting hypogene cave formation and mineralization in the Buda Thermal Karst, Hungary. — In: ZAHARIA, L., KIS, A. TOPA B., PApp, G. \& WeIsZburg, T. (eds): Acta Mineralogica Petrographica Abstract Series, Budapest, 864 p.

Poros, Z., Mindszenty, A., Molnár, F., Pironon, J., Győri, O., Ronchi, P. \& Szekeres, Z. 2012: Imprints of hydrocarbon-bearing basinal fluids on a karst system: mineralogical and fluid inclusion studies from the Buda Hills, Hungary. — International Journal of Earth Sciences 101/2, 429-452. https://doi.org/10.1007/s00531-011-0677-8

PoyANMEHR, Z. 2016a: Budai karsztrendszer utánpótlódási viszonyainak hidrodinamikai vizsgálata vizgeokémiai adatok figyelembevételével. — Doktori értekezés, Szegedi Tudományegyetem, 120 p.

PoyAnMEhr, Z. 2016b: A felszín alatti vízáramlás modellezése Budapest tágabb területén. — Földtani Közlöny 146/1, 61-70.

Royden, L. H. \& Horváth, F. 1988: The Pannonian Basin. A study in basin evolution. — Amer. Assoc. Petrol. Geol. Memoir 45, 402 p.

RusZkicZAY-RÜDIGER, Z., Fodor, L. \& Horváth, E. 2006: Neotectonic and landscape evolution of the Gödöllő Hills, central Pannonian Basin, Hungary. — Geolines 20, 116-118. https://doi.org/10.1016/j.gloplacha.2007.02.010 
RUSZKICZAY-RÜDIGER, Z., FodOR, L. I. \& HoRVÁTH, E. 2007: Neotectonics and Quaternary landscape evolution of the Gödöllő Hills, Central Pannonian Basin, Hungary. — Global and Planetary Change 58/1, 181-196. https://doi.org/10.1016/j.gloplacha.2007.02.010

RuszkicZAY-RÜdiger, Z., DunaI, T., BADA, G., Fodor, L. \& HorvÁth, E. 2005a: Middle to late Pleistocene uplift rate of the Hungarian Mountain Range at the Danube Bend, (Pannonian Basin) using in situ produced ${ }^{3} \mathrm{He}$. - Tectonophysics 410/1-4, 173-187. https://doi.org/10.1016/j.tecto.2005.02.017

RusZKICZAY-RÜDIGER, Z., Fodor, L., BADA, G., LEÉL-Ő́ssy, S., HorvÁth, E. \& DunAI, T. 2005b: Quantification of Quaternary vertical movements in the central Pannonian Basin: a review of chronologic data along the Danube River, Hungary. — Tectonophysics 410/14, 157-172. https://doi.org/10.1016/j.tecto.2005.05.048

Ruszkiczay-RÜdiger Z., Dunai T., Fodor L., BADA G., LeÉl-Őssy S. \& Horváth E. 2005c: A negyedidőszaki függőleges kéregmozgások számszerúsítése a Duna völgyében a korábbi kronológiai adatok és új, kozmogén ${ }^{3}$ He kitettségi kor mérések alapján (Quantifíing of Quaternary vertical movements of litosphere in the Duna Valley based on archive chronological and new ${ }^{3} \mathrm{He}$ exposure data). - Földtani Közlöny 135/3, 373-403.

SCHEUER G. \& SCHweITZER F. 1980: A Budai hévforrások fejlődéstörténete a felsố pannontól napjainkig. — Bull. Soc. Hidr. Hung. 60/11, 492-501.

SCHRÉTER Z. 1912: Harmadkori és pleisztocén hévforrások tevékenységének nyomai a Budai hegyekben (Traces of Tertiary and Pleistocene thermal spring activity in the Buda Mts). — A Magyar Királyi Földtani Intézet Évkönyve 19/5, $56 \mathrm{p}$.

Schubert F., Kóthay K., DéGi J., M. Tóth T., Bali E., SZabó C., Benkó Z. \& ZajaCZ Z. 2007: A szakirodalomban használt fluidum-és olvadékzárványokkal kapcsolatos kifejezések és szimbólumok szótára. — Földtani Közlöny 137/1, 83-102.

Szabó V., FóRIzs I., HAŁas, S., Pelc, A. \& DEÁK J. 2009: A budapesti hévizek szulfátjának eredete stabilizotópos mérések alapján. — A Miskolci Egyetem Közleménye, A sorozat, Bányászat 77, 73-81.

SZANYI, G., SURÁNYI, G. \& LEÉL-ỐSSY, S. 2012: Cave development and Quaternary uplift history in the Central Pannonian Basin derived from speleothem ages. — Quaternary Geochronology 14, 18-25. https://doi.org/10.1016/j.quageo.2012.09.001

TAKÁCs-BolNER, K. 1989: Regional and special genetic marks on the Pál-völgy cave, the largest cave of thermal water origin in Hungary. - Proceedings $10^{\text {th }}$ International Congress of Speleology, Budapest, 819-822.

То́тн, J. 1962: A theory of groundwater motion in small drainage basins in central Alberta, Canada. — Journal of Geophysical Research 67/11, 4375-4388. https://doi.org/10.1029/jz067i011p04375

То́тн, J. 1963: A theoretical analysis of groundwater flow in small drainage basins. — Journal of Geophysical Research 68/16, 47954812. https://doi.org/10.1029/jz068i016p04795

То́тн, J. 1999: Groundwater as a geologic agent: an overview of the causes, processes, and manifestations. — Hydrogeology Journal 7/1, 1-14. https://doi.org/10.1007/s100400050176

То́тн, J. 2009: Gravitational systems of groundwater flow: theory, evaluation, utilization. — Cambridge University Press. Gravitational systems of groundwater flow: theory, evaluation, utilization. https://doi.org/10.1007/s100400050176

VENDEL M. \& KisHÁZI P. 1964: Összefüggések melegforrások és karsztvizek között a Dunántúli-középhegységben megfigyelt viszonyok alapján. — MTA Múszaki Tudományos Osztályának Közleményei, 97-119.

Vető, I., Nagymarosy, A., Brukner-Wein, A., Hetényi, M. \& Sajgó, Cs. 1999: Salinity changes control isotopic composition and preservation of the organic matter: The Oligocene Tard Clay, Hungary revisited. - $19^{\text {th }}$ International Organic Geochemistry. TÜBITAK, Marmara Research Center, Istanbul, Turkey, 411-412.

VIRÁG M. 2016: Történeti áttekintés a budai barlangok keletkezéséről — a klasszikus karsztfejlődéstől a hipogén barlangképződésig. — Karszt és Barlang 2012-14, 24-46.

WeIN G. 1977: A Budai-hegység tektonikája (Tectonism of the Buda Hills). — MÁFI alkalmi kiadvány, 76 p.

Zimmerman, W. B. 2006: Multiphysics modeling with finite element methods. - World Scientific Publishing Co. Inc., 422 p. https://doi.org/10.1142/6141

Kézirat beérkezett: 2018. 01. 14. 